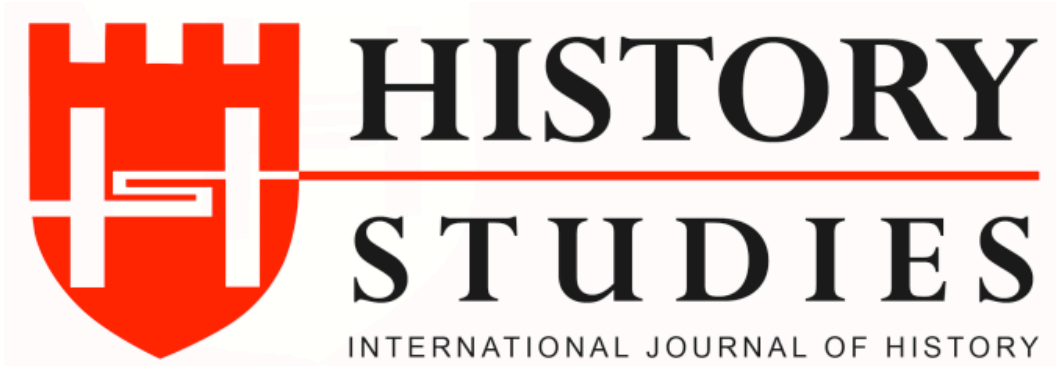

ISSN: 13094173 (Online) 1309 - 4688 (Print)

Volume 11 Issue 3, June 2019

DOI Number: 10.9737/hist.2019.752

Araştırma Makalesi

Makalenin Geliș Tarihi: 08.05.2019 Kabul Tarihi: 20.05.2019

Atıf Künyesi: Levent Kuru, "XVII. ve XVIII. Yüzyıllarda Bursa Medreseleri ve Müderris Tevcîhatı”, History Studies, 11/3, Haziran 2019, s. 1031-1058.

\title{
XVII. ve XVIII. Yüzyıllarda Bursa Medreseleri ve Müderris Tevcîhatı (Anadolu Kazasker Ruznamçelerine Göre)
}

\author{
Bursa Madrasahs and Mudarris Assignments in the $17^{\text {th }}$ and $18^{\text {th }}$ Centuries \\ (According to Anatolian Kadi'asker Agendas)
}

\author{
Dr. Levent Kuru \\ ORCID No: 0000-0001-5010-6637 \\ Trakya Üniversitesi
}

Öz: Osmanlı Devleti’nde ilmiye mensuplarının özlük işlerinin kaydedildiği kazasker ruznamçeleri ilk olarak XVI. yüzyılın ikinci yarısından itibaren düzenli bir şekilde tutulmaya başlanmıştır. Bu defterler kayıt formları açısından mülazemet ve hareket ruznamçeleri olmak üzere iki ana seriye ayrılırlar. Mülazemet ruznamçeleri ilmiye tarikine ilk defa girenlerin silke hangi yollarla dâhil olduklarına dair kayıtları ihtiva ederken, hareket ruznamçelerinde Anadolu ve Rumeli kazaskerlerinin yetki bölgelerinde bulanan mevleviyet seviyesinin altındaki kazalara ait kadı tevcîhatı vardır. Ayrıca bu ruznamçelerde Anadolu ve Rumeli kazaskerleri tarafindan yapılan müderris atamalarına dair kayıtlar da bulunur. Mülazemet ruznamçeleri sadece Rumeli kazaskerliği tarafından tutulurken, hareket ruznamçeleri Anadolu ve Rumeli kazaskerleri tarafından ayrı ayrı tutulmuşlardır.

Bâb-1 Meşîhat Arşivi ve Nuruosmaniye Kütüphanesi'nde bulunan XVII. ve XVIII. yüzyıla ait Anadolu kazasker ruznamçelerinin ana kaynak olarak kullanılmasıyla hazırlanan bu çalışmada Bursa medreseleri ele alınmıştır. Bursa medreselerine ya da Bursa medreselerinden başka medreselere yapılan müderris atamaları incelenerek teşkilatın işleyişine dair bir değerlendirme yapılmıştır. Ayrıca XVII. ve XVIII. yüzyılda Bursa'da bulunan 40 akçe altı medreselerin listesi çıkarılmıştır.

Anahtar kelimeler: Medrese, Müderris, Bursa, Anadolu kazaskeri.

Abstract: The first kadi'asker agendas containing records of personnel affairs of scholars in the Ottoman Empire were kept regularly as from the second half of the $16^{\text {th }}$ century. In terms of enrolment forms these agendas are differentiated into two main series: internship (mülazemet) agendasand movement (hareket) agendas. While internship agendas contained records about how persons were accepted for the scholar path for the first time, movement agendas consisted of kadi (judge) grants in administrative districts under the level of mevleviyet in jurisdiction areas of Anatolian and Rumelia kadi'asker. Besides, these agendas also contained records about mudarris (professor) assignments made by Anatolian 
and Rumelia kadi'askers. While internship agendas were only kept by the Rumelia kadi'asker, movement agendas were kept separately by the Anatolian and Rumelia kadi'asker.

This study addresses Bursa madrasahs by using Anatolian kadi'asker agendas from the $17^{\text {th }}$ and $18^{\text {th }}$ century maintained in Bâb-1 Meşîhat Archives and Nuruosmaniye Library as the main source. Mudarris assignments to or from Bursa madrasahs to others have been examined and an evaluation on the operation of this organization has been made in the frame of the data obtained from the agendas. Furthermore, a list of madrasahs in Bursa in the $17^{\text {th }}$ and $18^{\text {th }}$ century with a level under 40 asper has been prepared.

Key Words: Madrasah, Mudarris, Bursa, Anatolian kadi'asker.

\section{Giriş}

Sözlükte medrese, "okumak, anlamak, bir metni ögrenmek ve ezberlemek için tekrarlamak" anlamına gelen ders (dirâse) kökünden türeyen bir mekân ismidir. Yapılan araştırmalar İslam dünyasında medreselerin farklı zaman ve şartlarda doğduklarını göstermekle birlikte genel görüş eğitim-öğretim faaliyetleri için müstakil mekânların ilk olarak IX. yüzyıl sonlarında Türkistan ve Horasan bölgelerinde inşa edildikleri ve buralardan İslam âlemine yayıldıklarıdır. Devlet eliyle resmi bir kurum olarak ilk medrese ise X. yüzyılda Karahanlı hükümdarı Arslan Gazi Tafgac (öl. 1035) tarafından Merv'de yaptırılmıştır. Büyük Selçuklu veziri Nizâmü'l-Mülk tarafindan yaptırılan ve kurucusunun ismine atfen "Nizamiye Medresesi" adı verilen Bağdat medresesinin inşasına 1065'te başlanıp 1067'de tamamlanmıştır. Burası teşkilatlı bir yapıya sahip ilk medrese kabul edilir. Nizâmü'l-Mülk zamanında Bağdat'tan sonra İsfahan, Rey, Nişabur, Merv, Belh, Herat, Basra Amul gibi büyük merkezlerde medreseler yapılmış ve bunlar da "Nizamiye" adını almışlardır. Bu medreselerin eğitim müfredatlarında İslamî bilimlerin yanı sıra tıp, matematik, astronomi, tabiiyat, Arap Dili ve Edebiyatı, felsefe ve mantık gibi müspet bilim dallarına da yer verilmiştir. Büyük Selçuklulardan sonra medrese tesisi, bütün İslam dünyasında bir gelenek haline geldi. Böylece Nizamiye medreseleri örnek alınarak yeni medreseler kurulmaya başland1 ${ }^{1}$.

Anadolu'da ilk medreseler Beylikler Dönemi'nde kurulmaya başlanmıştır. Dânişmendliler ve Artuklular XII. yüzyılda, Selçuklular ise XIII. yüzyılda büyük medreseler yaptırmışlardır. İlhanlılar, Karamanoğulları ve diğer Anadolu Beylikleri de hâkimiyet sahalarında medreseler tesis etmişlerdir. Anadolu'da Selçuklu medreselerinin en yoğun olduğu yer devletin merkezi olan Konya idi. Altun Aba, Şeref Mesud, Karatay, Kemaliye, Nizamiye, Ata Bey, İnce Minare ve Sırçalı medreseleri Konya'da kurulan meşhur medreselerdir. Selçuklular Konya dışında Kayseri ve Sivas gibi İç Anadolu şehirlerini kültür merkezi haline getirirlerken, Selçuklu uç bölgelerinde ortaya çıkan beylikler, Kütahya, Balıkesir, Afyon,

\footnotetext{
${ }^{1}$ Ferit Develioğlu, Osmanlıca-Türkçe Ansiklopedik Lûgat, Ankara 1997, s. 599; Nebi Bozkurt, "Medrese", Diyanet Íslam Ansiklopedisi (=DIA), XXVIII, 323-327; Cahit Baltac1, XV-XVI. Yüzyıllarda Osmanlı Medreseleri, İstanbul 2005, s. 60-71; Mefail Hızlı, "Kuruluşundan Osmanlılara Kadar Medreseler", Uludă̆ Üniversitesi İlahiyat Fakültesi Dergisi, II/2, Bursa 1987, s. 273-281; Ersoy Taşdemirci, “Osmanlı İmparatorluğu'nda Medreseler”, Erciyes Üniversitesi Sosyal Bilimler Dergisi, III, Kayseri 1989, s. 519-532; Murat Akgündüz, Osmanlı Medreseleri -XIX. Astr-, İstanbul 2004, s. 17-18; Ekmeleddin İhsanoğlu, "Osmanlı Eğitim ve Bilim Kurumları", Osmanlı Devleti Tarihi, II, ed. Ekmeddin İhsanoğlu, IRCICA yay.,İstanbul 1994, s. 223-229; Mübahat S. Kütükoğlu, XX. Asra Erişen Istanbul Medreseleri, Ankara 2000, s. 3.
}

\section{History Studies}


Manisa ve Isparta gibi beylik merkezi olan şehirlerde yeni medreseler kurmuşlardır. Anadolu Selçukluları ve mirasçıları olan beylikler döneminde açılan medreseler Osmanlı öncesi Anadolu coğrafyasında entelektüel bir ortamın hazırlanmasını sağlamıştır. Osmanlılar da miras aldıkları bu bilgi birikimini oluşturdukları kurumlarda kullanmışlardır².

Osmanlı Devleti'nin kurucusu Osman Gazi zamanında Osmanlı'da müstakil medreselerin olmaması dolayısıyla eğitim-öğretim faaliyetleri cami ve tekkelerde yürütülmüştür. Osmanlılar ilk medreseyi devletin kurulmasından 32 yıl sonra Orhan Gazi döneminde İznik'te 1331 'de açmışlardır. "İznik Orhaniyesi” ismini taşıyan bu medresenin ilk müderrisi tahsilini Kayseri, Kahire ve Konya'da tamamlayan Davud-i Kayserî’dir. 1326'da Bursa'nın fethiyle birlikte Orhan Gazi tarafından manastırdan çevrilerek medrese haline getirilen Manastır Medresesi/Orhan Gazi Medresesi kurulmuş ve vakıflar tahsis edilmiştir. I. Murad, Yıldırım, Çelebi Mehmed, II. Murad ve bunların devlet adamları tarafından yaptırılan yirmi bir medrese ile Bursa zamanla bir ilim merkezi haline getirilmiştir. İslam fütuhat anlayışına bağlı olarak yapılan fetihler sonrası ele geçirilen bölgelerde tesis edilen irili ufaklı birçok medrese fethedilen yerlerin bir Türk-İslam yurdu haline gelmesini sağlamıştır ${ }^{3}$.

Medrese eğitiminin temel unsurunu müderrisler oluşturmuştur ve ilk dönem Osmanlı

medreselerinde görev alan müderrislerin menşei dikkate alındığında bu kişilerin Selçuklu ve beylikler döneminin önemli kültür merkezleri olan Kütahya, Manisa, Kastamonu gibi şehirlerdeki medrese muhitlerinde yetiştikleri görülmektedir. İhtisas alanlarını Suriye, Mısır, İran ve Mâveraünnehr gibi merkezlerde yapan bu âlimler sadece eğitim öğretim faaliyetlerini sürdürmekle kalmamışlar, bu işlerinin yanında Osmanlı bürokrasisinin yetişmiş insan ihtiyacını da karşılamışlardır ${ }^{4}$.

Büyük çoğunluğu bir vakıf kurumu olarak kurulan Osmanlı medreselerinde işleyiş ve mali kaynakların kullanılması vakıf senediyle belirlenirdi. Devlet ise medreseleri denetleme işi yanında görev yapacak müderrislerin tayin-terfi işlemlerini yerine getirirdi. Eğitim faaliyetlerinin başı sayılan müderrislerin dışında medreselerde idarî ve hizmetli kadroları da bulunurdu. Eğitim kadrosunu bir müderris ve onun yardımcılı̆̆ını üstlenen muîd oluştururken; idarî kadro, mütevelli başta olmak üzere kâtib, câbî, câbî kâtibi, mutemed ve noktacı gibi memurlardan meydana gelirdi. Son olarak hizmetli kadrosunda hâfız-1 kütüb (kütübhaneci), bevvâb (kapıc1), ferraş (temizlikçi), kennas-1 helâ (tuvalet temizleyicisi), sirâci (kandilci) bulunmaktayd ${ }^{5}$.

\footnotetext{
${ }^{2}$ Bilgin Aydın-Rıfat Günalan, "Ruus Defterlerine Göre XVI. Yüzyılda Osmanlı Müderrisleri”, Osmanlı'nın İzinde Prof. Dr. Mehmet İpşirli Armă̆anı, Hz. Feridun Emecen, vd., İstanbul 2013, s. 156-162; Ahmet Gül, Osmanl Medreselerinde Ë̆itim-Öğretim ve Bunlar Arasında Dâru'l-Hadîslerin Yeri, Ankara 1997, s. 14-34.

${ }^{3}$ Mehmet İpşirli, "Medrese" DİA, XXVIII, 327-333; İsmail Hakkı Uzunçarşıll, Osmanlı Devletinin İlmiye Teşkilâtı, Ankara 1988, s.1-3; Mustafa Bilge, Ilk Osmanl Medreseleri, İstanbul 1984, s. 5-63; Halil İnalcık, Osmanlı Imparatorluğu Klasik Çă̆ (1300-1600), çev. Ruşen Sezer, İstanbul 2003, s. 173-179.

${ }^{4}$ Aydın-Günalan, "Ruus Defterlerine Göre XVI. Yüzyılda Osmanlı Müderrisleri”, s. 156-162; İhsanoğlu, "Osmanlı Eğitim ve Bilim Kurumları", s. 223-229.

5 Mehmet Ali Ünal, Osmanlı Müesseseleri Tarihi, Isparta 2002, s. 114; Fahri Kayadibi, "Fatih Sultan Mehmed Döneminde Eğitim ve Bilim", İstanbul Üniversitesi İlahiyat Fakültesi Dergisi, VIII, İstanbul 2003, s. 1-18; Taşdemirci, "Osmanlı İmparatorluğu'nda Medreseler", s. 519-532.
}

\section{History Studies}


Selçuklulardan miras aldıkları medrese geleneğini kendi bünyelerinde geliştiren Osmanlılar, medreselerle ilgili ilk düzenlemeleri Yıldırım Bayezid ve Sultan Murad (II. Murad) zamanında yapılmışlardır. Bu dönemlerde medreselerde okutulacak dersler esas alınarak bir teşkilatlanmaya gidilmiştir. Esas kapsamlı düzenleme ise Fatih döneminde yapılmış ve merkezileşen devlet teşkilatı eğitimde de kendisini göstermiştir. Fatih'in ulema kökenli sadrazamı Mahmud Paşa, ilmiye teşkilatına ilk girişi sağlayan mülazemet sisteminin temelini atmıştır. Bunun yanında medreselerde görevlendirilen müderrislere 20 akçeden daha düşük yevmiye ödenen buk'a medreseleri dışında kalan ve medâris-i sâmiye olarak tanımlanan medreseleri ele alarak bunları bir silsileye bağlamıştır. Ulema, ümera ve hanedan üyelerinin yaptırdığı bu medreseler müderrislerin alacakları yevmiyeler göz önünde tutularak dirhem ve akçe üzerinden derecelendirilmiştir. Akçe bazında yapılan bu sınıflamanın dışında bir de okutulan derse göre bir ayrıma gidilmiştir. Böylece İstanbul'da Sahn-1 Seman ve Mûsıla-i sahn yani Tetimme medreselerinin yapımından sonra Osmanlı hudutları içindeki medreseler; Hâşiye-i Tecrid, Miftah, Kırkll, Hâriç, Dâhil ve Sahn-ı Semân olarak beş sınıfa ayrılmıştır ${ }^{6}$.

Hâşiye-i Tecrid medreselerinde görev yapan en alt düzeyde müderrislere 20-25 akçe yevmiye ödendiği için bu sınıfa girenlere yirmili medrese de denilmiştir. Aşağıdan yukarı ikinci sırada Miftah medreseleri gelmektedir ki buralarda görev alan müderrisler en az 30-35 akçe yevmiye aldıkları için bu medreselere otuzlu, Miftah medreselerinin üstünde olan Telvîh medreseleri ise yine müderrislere ödenen yevmiyeden dolayı kırklı medreseler olarak tanımlanmışlardır. Müderrislerine 50 akçe yevmiye verilen Hâriç ve Dâhil medreseleri ise Hâriç elli, Dâhil ellili isimleri verilmiştir. XVI. yüzyıldan sonra devlet erkânının yaptırdığı medreselerin statüsü Dâhil kategorisindeydi. Sahn-1 Semân medreselerinde görev yapan müderrislere de 50 akçe yevmiye verilmiştir. Ayasofya medresesi 60 akçelik olup buna altmışlı denmekteydi. XVI. yüzyılda Süleymaniye medreselerinin tesisi ile önceden yapılan tasnif daha da genişlemiştir. XVIII. yüzyıldan itibaren özellikle yüksek dereceli medreselerde yeni bir tasnife gidilmiş; iki hâriç, iki dâhil, iki sahn, iki altmışlı, üç Süleymaniye ve bir dârü'l-hadis medresesi oluşturulmuş ve medreselerin bu derecelendirilmesi Osmanlı Devleti'nin sonuna kadar devam etmiştir?

\section{Müderrislerin Tayinleri}

Medreselerin ortaya çıktığı X. yüzyıldan itibaren görülen ve Selçuklu veziri Nizâmü’lMülk’ün Nizâmiye medreselerini kurmasından sonra burada ders veren en yüksek rütbeli ilim

\footnotetext{
${ }^{6}$ İsmail Hakkı Uzunçarş11, Osmanlı Devletinin İlmiye Teşkilâtı, Ankara 1988, s. 2, 11-17; İpşirli, "Medrese", $327-$ 333; İlber Ortayl1, Türkiye Teşkilât ve İdare Tarihi, Ankara 2007, s. 233-235; Fahri Unan, "Osmanl İlmiye Tarîkinde "Pâye"li Tâyinler Yahut Devlete Kazanç Kapısı, Belleten, LXII/233, Ankara 1998, s. 42-64; Ahmet Ulusoy, Kuruluşundan 17. Yüzyıla Kadar Osmanlı Medreselerinde Eğitim-Öğretim Faaliyetleri, Selçuk Üniversitesi Sosyal Bilimler Enstitüsü Yüksek Lisans Tezi, Konya 2007, s. 34; Yasemin Beyazit, Osmanlı İlmiye Mesleğinde İstihdam (XVI. Yüzyıl), Ankara 2014, s. 188-191; Yasemin Beyazıt, "Osmanlı Eğitim Sistemi İçinde Buk'a Medreseleri”, Osmanlı Medreseleri: Eğitim, Yönetim ve Finans, ed. Fuat Aydın, Mahmud Zengin, vd., İstanbul 2018, s. 447-472; Mehmet İpşirli, "Buk'a”, DİA, VI, 386-387.

7 İpşirli, "Medrese", 327-333; Baltacı, XV-XVI. Yüzyıllarda Osmanlı Medreseleri, s. 73-75; Akgündüz, Osmanlı Medreseleri -XIX Asır-, s. 20-21; Mefail Hızlı, "Osmanlı Medreselerinde Okutulan Dersler ve Eserler", Uludăg Üniversitesi İlahiyat Fakültesi Dergisi, XVII/1, Bursa 2008, s. 25-46; M. Kemal Özergin, "Eski Bir Rûznâme’ye Göre İstanbul ve Rumeli Medreseleri", İstanbul Üniversitesi Edebiyat Fakültesi Tarih Enstitüsü Dergisi (IÜEFD), IV-V, İstanbul 1974, s. 263-290; Aydın-Günalan, “Ruus Defterlerine Göre XVI. Yüzyılda Osmanlı Müderrisleri”, s. $156-162$
}

\section{History Studies}


adamları için kullanılarak resmî bir mahiyet kazanan "müderris" kelimesi, "okumak, anlamak, bir metni öğrenmek için tekrar etmek" anlamındaki ders kökünün "tef'îl” kalıbında türemiştir".

Osmanlı eğitim sistemi içinde de medreselerde çeşitli dersler veren hocalara müderris denilmiştir. Medreselerin ortadan kalkmasından sonra da yüksek dereceli okullarda görev yapan hocaları için bu unvan kullanılmaya devam etmiştir. Osmanlı'da eğitim-öğretim faaliyetlerinin temeli müderrislere dayanmaktaydı. Bu bağlamda talebenin medreseden mezuniyet belgesi olan icâzetnâmelere medresenin değil müderrislerin ve okutulan kitapların isimleri yazılmıştır. Bu uygulama klasik İslam medrese sisteminin Osmanlı eğitim sistemine yansimasidır'.

Osmanlı medrese silsilesi içinde eğitim hayatını tamamlayarak icazetlerini alan danişmendler $^{10}$ ilmiye teşkilatına girerek medreselerde tedris hizmetlerini vermeye hak kazanmış olurlardı. Kendilerinde "ehl-i ilim ve sâhib-i fazîlet, sâhib-i haysiyyet" gibi vasıflar aranan müderris adayları öncelikle Rumeli kazaskerinin salahiyetinde olan mülazemet ruznamçesine isimlerini yazdırırlar ve tercihlerine göre Anadolu ve Rumeli kazaskerliklerine bağlı olarak görev yapmak üzere sıra beklerlerdi ${ }^{11}$. Teşkilat içindeki müderrislerin kariyer basamakları çıkarılan kanunnamelerle belirlenmiştir ${ }^{12}$.

Müderrislerin atamalarında dönemsel olarak farklılıklar olmakla birlikte şeyhülislam ve kazaskerler başlıca yetkililer olmuşlardır. XVI. yüzyılın ikinci yarısına kadar bütün müderris ve kadı atamaları kazaskerlerin salahiyetinde olup atanacak müderris veya kadı ismi okunarak padişaha arz edilir ve ataması gerçekleşirdi. Ebussuud Efendi’nin şeyhülislamlığında ise Hâşiye-i Tecrit (yirmili), Miftah (otuzlu) ve Telvîh (kırklı) medreselerinde görevlendirilen müderrisler ile $150^{13}$ akçeye kadar olan kazalara kadı tayinleri yine kazaskerler tarafından yapılmıştır. Buna karşılık Hâriç ve daha yukarı seviyede olan medreselere atanacak müderrisler ile mevleviyet kadılıklarına yapılacak tayinler, şeyhülislamın sadrazam vasıtasıyla inhası üzerine olmuştur ${ }^{14}$.

Şeyhülislamlar yaptıkları kadı ve müderris atamalarına dair ayrı defterler tutmayıp, bu kayıtları diğer bürokratik atamaların yer aldığı ruus defterlerine işlemişlerdir. Rumeli ve

\footnotetext{
${ }^{8}$ Nebi Bozkurt, "Müderris", DİA, XXXI, 467-468; Develioğlu, Osmanlıca-Türkçe Ansiklopedik Lûgat, s. 708.

${ }^{9}$ Mehmet İpşirli, "Müderris", DİA, XXXI, 468-470.

${ }^{10}$ Koçi Bey bu süreci şöyle tarif eder: “...Evvelce ilim öğrenmek isteyen bir kişi danişmend olmak isterse ulemadan birisi harekete geçer, evvela ondan mahreç dersi okur, yeteneği ve kabiliyeti görüldükten sonra müderrislerden birine gönderirdi. Ondan ötekine [gönderilir] böyle böyle hâriçte, dahilde ve sahnda nice müddet danişmed olur; sonunda istediği yerde karar kılıp, yolu [sırası] geldiğinde mülazım olur ve ruznamçe-i hümayuna adı yazılırdı..." (bk. Koçi Bey Risaleleri, haz. Seda Çakmakçığlu, İstanbul 2008, s. 46-47).

${ }^{11}$ Danişmendlerin mülazım yazılabilme yollarına dair ayrıntılı bilgi için (bk. Beyazıt, Osmanlı İlmiye Mesleğinde İstihdam (XVI. Yüzyll), s. 49-97).

${ }^{12}$ Fatih Kanunâmesi'nde müderrislerin teşkilat içinde ilerlemesine dair şu ifadeler geçmektedir: “ Ve ibtidâ yeni mülâzım yirmi akça medreseye, andan yirmi beş andan otuz, andan otuz beş, andan kırık, andan kırk beş, andan elli akçaya vâsıl olur. Elli akça müderris cümle ağaların üstüne oturur. Sahn'a varduktan sonra beş yüz akça kadı olup, andan kadı'asker olurlar" (bk. Fatih Sultan Mehmed, Kânûnnâme-i Âl-i Osman (Tahlil ve Karşılaştırmalı Metin), Haz. Abdülkadir Özcan, İstanbul 2003, s. 11).

${ }^{13} \mathrm{Bu}$ değer yüzyıllara göre değişmektedir. XVII. yüzyılda 300 akçeye, XVIII. yüzyılda ise 499 akçeye kadar olan atamalar ruznamçelere kaydedilmişlerdir. $\mathrm{Bu}$ statüde olan kadılıklara "kasaba kadılıkları", atama yetkisi şeyhülislamda olan kadılıklara ise "mevleviyet" kadılıkları denilmiştir.

${ }^{14}$ Uzunçarşı1lı, Osmanlı Devletinin İlmiye Teşkilâtı, s. 59.
} 
Anadolu kazaskerleri ise sorumlu oldukları bölgelerde medrese ve kazalara yaptıkları müderris ve kadı atamaları için müstakil defterler tutmuşlar ve tüm atamaları ruznamçe ismi verilen bu defterlere kaydetmişlerdir. Ruznamçeye kaydı yapılmayan atama işlemi ise hükümsüz sayılmıştır. Böylece XVI. yüzyılın ikinci yarısından itibaren 40 akçeye kadar olan müderris atamalarıyla kaza (kasaba) kadılıklarına yapılan atamalara dair kayıtlar ruznamçelerde, 50 ve üzeri akçe yevmiye alan müderrislerle mevleviyet kadılıklarının tayin kayıtları ruus defterlerinde yer almışırır.

\section{Kazasker Ruznamçeleri}

Osmanlı devletinde XVI. yüzyılın ikinci yarısından itibaren ortaya çıkan kazasker ruznamçelerini iki ana gruba ayrılırlar. Mülazemet ruznamçeleri olarak isimlendirilen defter serileri teşkilata ilk giriş kayıtlarını içerirler ve bu deftere bir anlamda ilmiye teşkilatının kütük defterleridir. Osmanlı coğrafyasının her yerine dağılmış olarak faaliyet gösteren medreselerde okutulan dersleri tamamlayarak icâzetini alan danişmedler; muîdlik, tezkirecilik, fetvâ eminliği, teşrîf, müstakillen, mevtâdan olmak üzere farklı yollarla isimlerini mülazemet ruznamçesine yazdırmışlardır. Müderrisler ve mollalar, danişmedlerine ne vesile ile mülazım tayin edildiklerini açıklayan bir tezkire verirler ve onlar da ellerindeki bu tezkirelerle Rumeli kazaskerliğine başvururlardı. Ayrıca zaman zaman ilan edilen nevbet ile yukarıda belirtilen yollardan biriyle ilmiye tarikine girememiş danişmedler de silke dâhil olmuşlardır. Ebussuud Efendi'nin Rumeli kazaskerliği (1573-1545) döneminde bu defterler müstakil olarak tutulmaya başlanmıştır. Böylece öncelikle ilmiye tarikine ilgisi olmayanların teşkilata girmeleri engellenmek istendiği gibi ulemanın mülazım verme sayıları belirlenerek bir sınırlama getirilmiş ve artan mülazım sayısı kontrol edilmeye çalışılmıştır. Bu dönemde nevbetin de yedi yılda bir yapılması kanun haline gelse de bu süreye pek riayet edilmemiştir. Mülazemet ruznamçelerinden günümüze ulaşan en erken tarihlisi 951-959 (1544-1545/1551-1552) y1lları arasındaki kayıtları içeriir ${ }^{15}$.

Kazasker ruznamçelerinde ikinci seriyi hareket ruznamçeleri oluşturur ${ }^{16}$. İlmiye teşkilatı içerisinde bulunan ve kazaskerlerin yetki sahasındaki kaza ve medreselerde görev alan kadı ve müderrislerin kayıtlarının yer aldığı bu defterler göreve gelen her kazasker için ayrı ayrı tutulmuştur. Ayrıca mülazemet ruznamçelerinin aksine hareket ruznamçelerinde devletin Rumeli canibi, Ege ve Akdeniz adalarında bulunan kaza ve medreseler için yetkili makam Rumeli kazaskerliğidir. Anadolu kazaskerliği ise başta Anadolu olmak üzere Suriye, İran, Irak, Arap Yarımadası, Misır ve Kuzey Afrika'da bulunan kazalar ile medreselerde yetkilidir ${ }^{17}$.

\footnotetext{
${ }^{15}$ Cahit Baltacı, "Kâdî-asker Rûz-nâmçeleri’nin Tarihî ve Kültürel Ehemmiyeti”, İslam Medeniyet Mecmuası, IV/1, İstanbul 1979, s. 55-100; Cahit Baltac1, "The İmportence Of The Kadı Registers For The Islamic World", Studies On Turkish-Arab Relations, II, İstanbul 1987, s. 166-169; İsmail Erünsal, "Nuruosmaniye Kütüphanesinde Bulunan Bazı Kazasker Ruznâmçeleri”, İstanbul Üniveresitesi Edebiyat Fakültesi Tarih Enstitüsü Dergisi (IÜEFD), X-XI, İstanbul 1981, s. 3-15; İsmail Erünsal, Osmanlı Kültür Tarihinin Bilinmeyenleri, İstanbul 2014, s. 401-447; Yasemin Beyazıt, "Osmanlı İlmiyye Bürokrasisinde Şeyhülislâmlığın Değişen Rolü ve Mülâzemet Sistemi (XVI-XVIII. Yüzy1llar)”, Belleten, LXVIII/267, Ankara 2009, s. 423-441.

${ }^{16} \mathrm{Bu}$ tanımlamayı kazasker ruznamçeleri üzerine ilk kapsamlı çalışmayı yapan Yasemin Beyazıt yapmıştır (bk. Yasemin Beyazıt, Osmanlı Ilmiye Mesleğinde İstihdam (XVI. Yüzyıl), s. 12; Yasemin Beyazıt, "Kadasker Ruznâmçelerinde Tipoloji ve Yeterlilik", Özer Ergenç Armăğanı, ed. Ümit Ekin, İstanbul 2013, s. 97-112).

17 Mehmet İpşirli, "Kazasker", DİA, XXV, 140-143; İlber Ortaylı, Hukuk ve İdare Adamı Olarak Osmanl Devletinde Kadı, Ankara 1994, s. 12; Levent Kuru, Kazasker Ruznamçelerine Göre 18. Yüzyılın Illk Yarısında
} 
Çivizâde Mehmed Efendi'nin ikinci defa Rumeli kazaskeri olduğu dönemde tutulmuş ve 29 Saferü'l-hayr 989 (4 Nisan 1581) ile 29 Zi'l-hicce 989 (22 Ocak 1582) tarihlerini kapsayan on aylık dönemde Rumeli kaza ve medreselerine yapılan atama işlemlerinin kayıt edildiği bu defter şu ana kadar tespit edilen en erken tarihli ruznamçedir ${ }^{18}$.

İçerdiği bilgiler itibariyle ilmiye teşkilatının temel kaynaklarından olan mülazemet ve hareket ruznamçelerinden bugüne kadar 429 tanesi tespit edilmiştir. Bâb-1 Meşîhat Şeyhülislâmlık Arşivi ve Nuruosmaniye Kütüphanesi'nde bulunan bu kaynaklar araştırmacıların hizmetine sunulmuştur. Bâb-1 Meşîhat Şeyhülislâmlık Arşivi'nde 377 kazasker ruznamçesi vardır. Cahit Baltacı tarafından keşfedilen ve bir makale ile ilim dünyasına tanıtılan bu defterlerin 257'si Rumeli kazaskerliğine ait iken, 122 adet ruznamçe de Anadolu kazaskerliğinindir ${ }^{19}$. Nuruosmaniye Kütüphanesi'nde ise 52 ruznamçe vardır ve çoğunluğu Anadolu kazaskerliği tarafından yapılmış atama kayıtlarını ihtiva eder. Bu defterleri de İsmail Erünsal yayınladığı makale ile tanıtmıştır ${ }^{20}$. Hareket ruznamçeleri, Anadolu ve Rumeli kazaskerliklerine bağlı olarak çalışan ilmiye mensuplarının tayin, terfi ve azillerine ait kayıtlarını içerir. Bu kayıtlara ek olarak teşkilatın işleyişine dair ferman, buyruldu, arz ve arzuhaller de defterlerde yer almaktadir.

\section{XVII. ve XVIII. Yüzyıl Anadolu Kazasker Ruznamçeleri}

Anadolu kazaskerliği tarafından XVII. ve XVIII. yüzyıllarda yapılmış kadı ve müderris atamalarını içeren toplam 99 ruznamçe vardır. Bu defterlerin 56 tanesi Meşîhat Arşivi'nde, 43'ü ise Nuruosmaniye Kütüphanesi'ndedir ${ }^{21}$. Anadolu kazasker ruznamçesi olarak tanımlanan bu defterlerin kayıtları incelendiğinde Meşîhat Arşivi'nde bulunan 56 defterin 32 tanesinde sadece kadı atamalarına, 24 defter de hem kadı hem de müderris atamalarına dair kayıtlar vardır.

Nuruosmaniye Kütüphanesi'nde bulunan 43 ruznamçenin $21^{22}$ tanesinde sadece kadı atamaları, varken kalan 22 ruznamçede kadıların yanında müderris atamaları da vardır. Diğer bir ifadeyle iki arşivde bulunan toplam 99 ruznamçenin 46'sında müderris atamalarıyla ilgili işlemler vardır. $\mathrm{Bu}$ defterlere ek olarak Meşîhat Arşivi’nde Rumeli kazasker ruznamçeleri olarak kataloglanmış bir defterde ise Rumeli, Anadolu ve Mısır kazalarına yapılan kadı atamalarıyla birlikte Anadolu medreselerine yapılan müderris atamalarını içeren bir varaklık bir kısım da bulunur ${ }^{23}$. Dolayısıyla bu çalışma kapsamında toplam 47 defterdeki veriler incelenerek değerlendirmesi yapılmıştır.

Rumeli'de Kadılı Müessesesi, Marmara Üniversitesi Türkiyat Araştırmaları Enstitüsü, Doktora Tezi, İstanbul 2016, s. 17.

${ }^{18}$ Yasemin Beyazıt, Kadıasker Atama Ruznâmçelerinden "Çivizâde Mehmed Efendi Ruznamçesi", Ankara 2018.

${ }^{19}$ Baltac1, "Kâdî-asker Rûz-nâmçeleri'nin Tarihî ve Kültürel Ehemmiyeti”, s. 55-100.

${ }^{20}$ Erünsal, Osmanlı Kültür Tarihinin Bilinmeyenleri, s. 401-447.

${ }^{21}$ Bilgin Aydın, İlhami Yurdakul, İsmail Kurt, Bâb-ı Meşîhat Şeyhülislâmlık Arşivi Defter Kataloğu, İstanbul 2006, s. 55-56; Erünsal, Osmanlı Kültür Tarihinin Bilinmeyenleri, s. 401-447; Meşîhat Arşivi'nde bulunan Anadolu kazaskerliğine ait 56 defterden 4 tanesi kataloglara Rumeli kazaskerliği ruznamçesi olarak geçse de bu defterler Anadolu kazaskerliği tarafından tutulmuşlardır (bk. MA, RKR, 60; 63; 64; 81).

${ }^{22} \mathrm{Bu}$ rakam Üsküdar medreseleri üzerine yaptığımız çalışmada sehven 11 olarak yazılmıştır (bk. Levent Kuru, XVII. ve XVIII. Yüzyıllarda Üsküdar Medreseleri ve Müderrisleri (Anadolu Kazasker Ruznamçelerine Göre), Üsküdar Sempozyumu X 19-20-21 Ekim 2018 Bildiriler Kitabı I, İstanbul 2019, s. 365-394).

${ }^{23}$ MA, RKR, 228/51, vr. 14a. 
İncelenen defterler içinde en erken tarihlisi XVII. yüzyılın ikinci yarısına aittir ve 10761077 (1665-1666) yılları arasında yapılmış atama işlemlerini içerir ${ }^{24}$. Bu defterdeki müderris kayıtları 1 C 1076'dan başlarr ${ }^{25}$. En geç tarihli ruznamçe ise XVIII. yüzyılın ilk yarısındaki atama işlemlerine dairdir ve defterin tarihi 1147 (1734)' $\mathrm{dir}^{26}$. Bu defterdeki son müderris ataması $1 \mathrm{C} 1147^{\prime}$ de yapılmıştır ${ }^{27}$. İlk defter ile son defter arasındaki tarih aralığı 69 sene olmakla birlikte bazı yıllara ait ruznamçelerin eksikliği sebebiyle bu çalışma verileri yaklaşık 55-56 yılın işlemlerini kapsamaktadır.

Anadolu kazaskerliği tarafından XVII. yüzyılın ilk yarısında tutulmuş ruznamçeler arşivlerimizde bulunmadığından bu dönemle ilgili bir veri elde edilememiştir. Anadolu kazaskerliğine ait XVIII. yüzyıl defterlerinde ise 1734 tarihli defterden sonraki ruznamçelerde sadece kadı atamaları vardır. Bu sebeple 1734 sonrasında yapılan müderris atamalarına dair veriler de elde edilememiştir ${ }^{28}$.

Anadolu kazaskerliğinin yetki sahasındaki kazalarda faaliyet gösteren medreselerde görevlendirilen müderrislerin işlemleri incelendiğinde 55-56 y1llık dönemi kapsayan 47 defterde toplam $3777^{29}$ müderris atama kaydı tespit edilmiştir. Bu atamaların nerelere yapıldığına dair sayısal bilgiler Grafik 1'de gösterilmektedir.

\footnotetext{
${ }^{24} \mathrm{Bu}$ dönemde Anadolu kazaskeri Şeyhizâde Abdurrahman Efendi'dir (bk. Nuran Bakır, XVII. Asrın İkinci Yarısında Payeli ve Bilfiil Anadolu ve Rumeli Kazaskerleri, İstanbul Üniversitesi Edebiyat Fakültesi Tarih Bölümü, Mezuniyet Tezi, İstanbul 1966, s. 18).

${ }^{25}$ MA, AKR, 435/1.

${ }^{26} \mathrm{Bu}$ dönemde Anadolu kazaskeri Raşid Mehmed Efendi'dir (bk. Gülsen Gökçay, XVIII. Asrın İlk Yarısında Anadolu ve Rumeli Kazaskerleri, İstanbul Üniversitesi Edebiyat Fakültesi Tarih Bölümü, Mezuniyet Tezi, İstanbul 1964, s. 73).

${ }^{27}$ NOK, AKR, 5193/37.

${ }^{28} \mathrm{Bu}$ tarihten sonra Anadolu kazasker ruznamçelerinde müderris ataması bulunmamaktadır.

${ }^{29} \mathrm{Bu}$ sayı Üsküdar medreselerine dair yaptığımız çalıșmada 3769 olarak verilmiştir (bk. Kuru, XVII. ve XVIII. Yüzy1llarda Üsküdar Medreseleri ve Müderrisleri (Anadolu Kazasker Ruznamçelerine Göre), s. 365-394). Ancak XVII. ve XVIII. yüzyıl Anadolu kazasker ruznamçelerinde yeni tespit edilen 8 atama işlemiyle -Üsküdar medreselerine 4, Bursa medreselerine 3, diğer yerler 1- toplam tevcîhat sayısı 3777 olarak tespit edilmiştir.
}

\section{History Studies}


Grafik 1: Anadolu Kazaskerliği Müderris Atamaları (1 C 1076-1 C 1147)

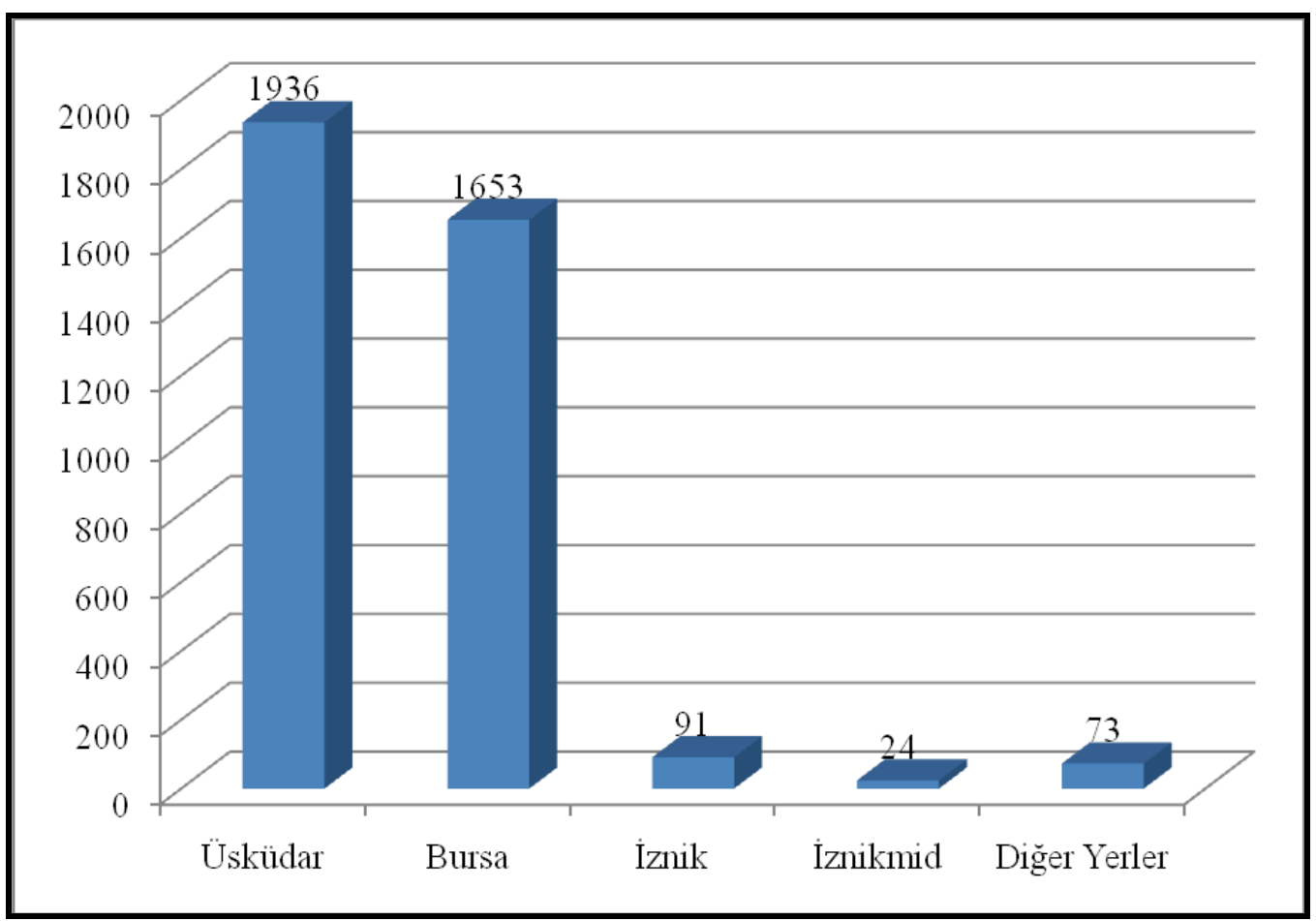

Toplam atamaların 1936 tanesi Üsküdar medreselerine yapılmıştır. Bu rakam toplam atama işlemlerinin \%51'ini kapsamaktadır. Ruznamçelerin kayıtlarına göre ikinci sırada en fazla atama işlemi Bursa'da bulunan medreseler için yapılmıştır. Bursa medreselerine ait 1653 işlem kaydı ise toplamın \%44'ünü oluşturur. Üçüncü sırayı 91 kayıt ile İznik medreseleri alırken, İznikmid medreselerine 24 atama işlemi tespit edilmiştir. Geriye kalan 73 atama işlemi ise Kastamonu, Akşehir, Ermenak, Manisa, Nazilli, Tosya gibi Anadolu'nun çeşitli kazalarında yer alan medreselere aittir. Ayrıca grafikte diğer yerler olarak gösterilen 73 müderris atamasının içinde 5 tanede İstanbul medreselerine yapılan atama kayıtları vardır ${ }^{30}$. Bu 5 atama kaydının Anadolu kazasker ruznamçelerinde olması sıra dışı bir durumdur. Çünkü İstanbul medreseleri Rumeli kazaskerlerinin salahiyeti altındadır. Bu kayıtlar sehven Anadolu ruznamçelerine kaydedilmiş olabilirler.

\section{XVII. ve XVIII. Yüzyılda Bursa Medreseleri}

XVII. ve XVIII. yüzyıllarda Anadolu kazasker ruznamçelerinde Bursa medreseleri olarak yapılan 1653 atama işleminde 191 değiş̧ik medrese ismi geçmektedir. Ancak bu rakam ilgili dönemde Bursa'daki medrese sayısını yansıtmamaktadır. Kâtiplerin medrese isimleri konusunda standart bir düzende hareket etmemeleri sayının artmasına sebep olmuştur. Örneğin; incelenen dönem içinde Bursa'da Abdülkerim medresesi olarak kaydedilmiş bir medrese vardır. Ancak bunun dışında Abdülkerim Çavuş ve Seyyid Abdülkerim olarak kayıt edilmiş iki medrese ismi daha geçmektedir. Bu durum birkaç açıdan değerlendirilebilir. İlk olarak herhangi bir

${ }^{30}$ MA, AKR, 459/24, vr. 76b; 460/25, vr. 72b, 
unvan kullanılmadan Abdülkerim olarak kayıt edilen diğerlerinden farklı bir medrese olabilir. İkincisi Abdülkerim medresesi, Seyyid veya Çavuş unvanlı Abdülkerim medreselerinden birisiyle aynı medrese olabilir. Bunların dışında üçüncü bir ihtimal üç farklı medrese gibi görünen bu yerlerin aynı olmalarıdır. Buralara yapılan atama işlemlerinin tarihleri dikkate alındığında farklı dönemlere ait oldukları görülmektedir ${ }^{31}$. Benzer bir örnek Yıldırım Bayezid medresesine dair kayıtlarda rastlanmaktadır. Kâtipler bu medreseyi bazen Yıldırım bazen Bayezid Han bazen de Yıldırım Bayezid Han şeklinde kayıt etmişlerdir. Medreselerin isimleriyle ilgili bu sıkıntıların yanında A $\breve{g} a$, Paşa, Efendi ve Çelebi gibi unvanların ve mollamenla gibi aynı anlamlı terimlerin kullanımı incelenen dönemdeki listenin kabarmasına ve sayının 191'leri bulmasına sebep olmuştur. Ayrıca kâtiplerin Bursa'da olmayan bazı medreseleri sehven Bursa olarak kayıt etmeleri bir diğer sorun olarak karşımıza çıkmaktadır. Literatürde bilinen medreselerle ilgili listede bir birleştirme ve düzeltme işlemi yapılabilse de ilgili konuya dair mevcut çalışmalarda ismi geçmeyen medreselerle ilgili isim karmaşalığını kazasker ruznamçelerindeki kayıtlarla düzeltmek olanaksızdır ${ }^{32} . \mathrm{Bu}$ durumda ruznamçelerindeki bilgilerden Bursa'da bulunan medrese sayısının kesin tespitini yapmak mümkün değildir. Bize de herhangi bir karışıklığa ve hataya sebep olmamak için ekte verdiğimiz medrese listesini ruznamçelerde geçtiği şekilde birleştirme ve düzeltme yapmadan hazırladık. Tespit edebildiğimiz bazı durumları dipnot ile açıklamaya çalıştık.

\section{XVII. ve XVIII. Yüzyılda Bursa Müderrisleri}

XVII. ve XVIII. yüzyıllarda Anadolu kazaskerinin yetkisi altındaki medreselere yapılan müderris atamaları incelendiğinde bu dönemde Bursa medreselerine dair en erken tarihli tevcîh işleminin 1 C 1076 (9 Aralık 1665)'da yapıldığı tespit edilmiştir. En geç tarihli atama kaydı ise 1 L 1145 (17 Mart 1733)'tir. İki tarih arası dönem yaklaşık 68 yıldır. Ancak ruznamçelerin eksikliği sebebiyle arada boşluklar da vardır. Bursa medreselerine görevlendirilme işlemi yapılan müderrislerden 38'nin yanına "merfû" kaydı düşülmüş ve bu görevlendirmeler iptal edilmiştir $^{33}$. Bir atama işlemi ise ruznamçenin eksikliği sebebiyle yarım kalmışıır" ${ }^{34}$ Kazaskerlik dairesinin işleyişi ve müderrislerin kariyer sistemi üzerine yoğunlaştığımız bu çalışmada ilgili dönemde Bursa medreselerine yapılan ancak daha sonra iptal edilen işlemler ruznamçe kayıtlarının bütünlüğünü bozmamak için değerlendirme genel değerlendirmeye dâhil edilmiştir.

Bursa medreselerine atanan müderrislerin önceki görev yerleri göz önüne alındığında 877 kişinin İstanbul'daki bir medresede görev yaptıktan sonra infisal dönemlerini tamamlayarak Bursa'ya tayin edildikleri tespit edilmiştir. Ruznamçe verilerine göre 312 müderrisin de Bursa içinde yer değiş̧irdiği görülmektedir. Üsküdar'dan Bursa'ya geçen müderris sayısı ise 162 'dir. Edirne'de tedris hizmetini yerine getirdikten sonra Bursa'ya gelen

\footnotetext{
31 Abdülkerim medresesine 1076-1080; Seyyid Abdülkerim medresesine 1082-1086; Abdülkerim Çavuş medresesine 1106-1109 tarihleri arasında atamalar yapılmıştır.

${ }^{32}$ Bursa medreseleri üzerine bugüne kadar en kapsamlı çalışma Mefail Hızlı tarafından hazırlanmıştır. Ancak bu çalışma XIV-XVI. yüzyıllar arasında Bursa'da yapılan medreseleri kapsamaktadır ve daha sonra kurulan medreseler bu çalışmada yoktur. Mefail Hızlı eserinde XVI. yüzyılın sonlarına doğru Bursa'daki medrese sayısının 50'yı bulduğunu belirtmiştir (bk. Mefail Hızlı, Osmanlı Klasik Döneminde Bursa Medreseleri, İstanbul 1998, s. 14).

${ }^{33}$ NOK, AKR, 5193/17, vr. 29b, 30a, 31b, 32b; MA, AKR, 443/8, s. 176-179; MA, RKR, 240/ 63, vr. 21b, 22a, 22b; MA, RKR, 241/64, s. 81-82, 84 .

${ }^{34}$ NOK, AKR, 5193/23, vr. 47b.
} 
müderris adedi de $67^{\prime}$ dir. Bu rakamlar Bursa medreselerinin insan kaynağının ağırlıklı olarak İstanbul, Edirne, Üsküdar ve Bursa'dan sağlandığını göstermektedir. Bu yerlerin dışında İznik, İznikmid, Galata, Gelibolu, Eyüp, Beşiktaş, Kasımpaşa ve Kastamonu gibi çeşitli yerlerde görev yapmış müderrisler de Bursa medreselerinde görevlendirilmiştir.

XVII. ve XVIII. yüzyıl Anadolu kazasker ruznamçelerindeki Bursa medreselerine atanan müderrislerin menşeine dair rakamlar ve yüzdelik dağılım Grafik 2'de verilmiştir.

\section{Grafik 2: Bursa Medreselerinde Görevli Müderrislerin Önceki Görev Yerleri}

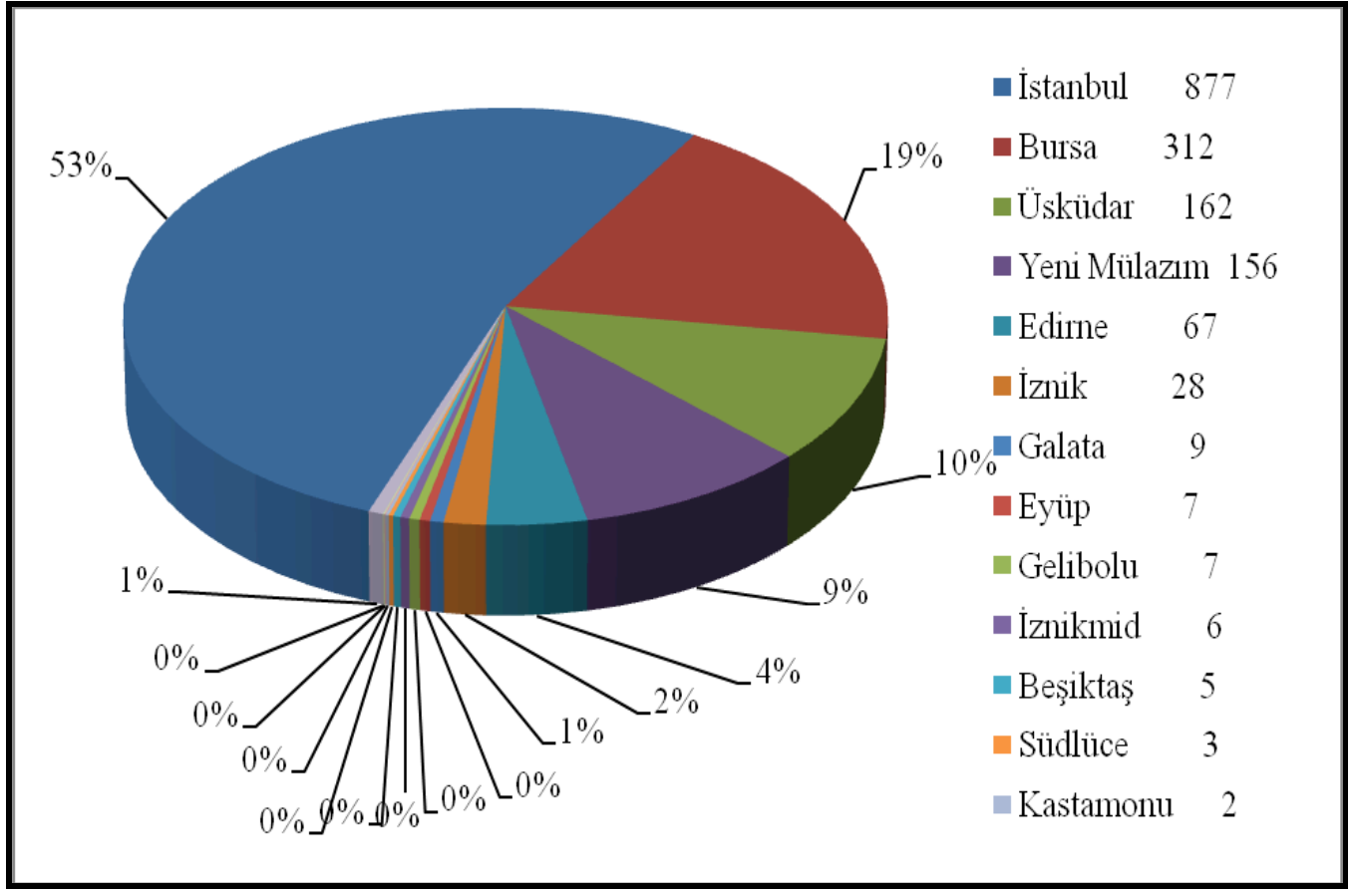

Grafik 2'ye göre Bursa'ya ataman müderrislerin \% 86'sının İstanbul, Bursa ve Üsküdar'daki medreselerinden munfasıl oldukları görülmektedir. Bunların dışında yeni mülazım olarak tanımlanan ve ilk defa bir medreseye atanarak müderrislik hizmetine başlayan 156 kişi de toplam atamaların \% 9'unu oluşturur. Atama kayıtlarında yeni mülazımların hangi yolla teşkilata girdikleri bilgisini vermektedir. Yeni mülazım kayıtlarında dikkati çeken bir diğer durum daha önce bir medresede görev alan müderrislerin sadece isimleri verilirken yeni mülazım atamalarında baba isimleri ve memleketlerine dair bilgiler de bulunur. XVII. ve XVIII. yüzyılda ilk defa Bursa'da bir medreseye atanarak göreve başlayan müderrislerin hangi yollar ile teşkilata dâhil oldukları Grafik 3'te gösterilmiştir. 
Grafik 3: Göreve İlk Defa Bursa'da Başlayan Müderrislerin İlmiye Teşkilatına Giriş

Yolları

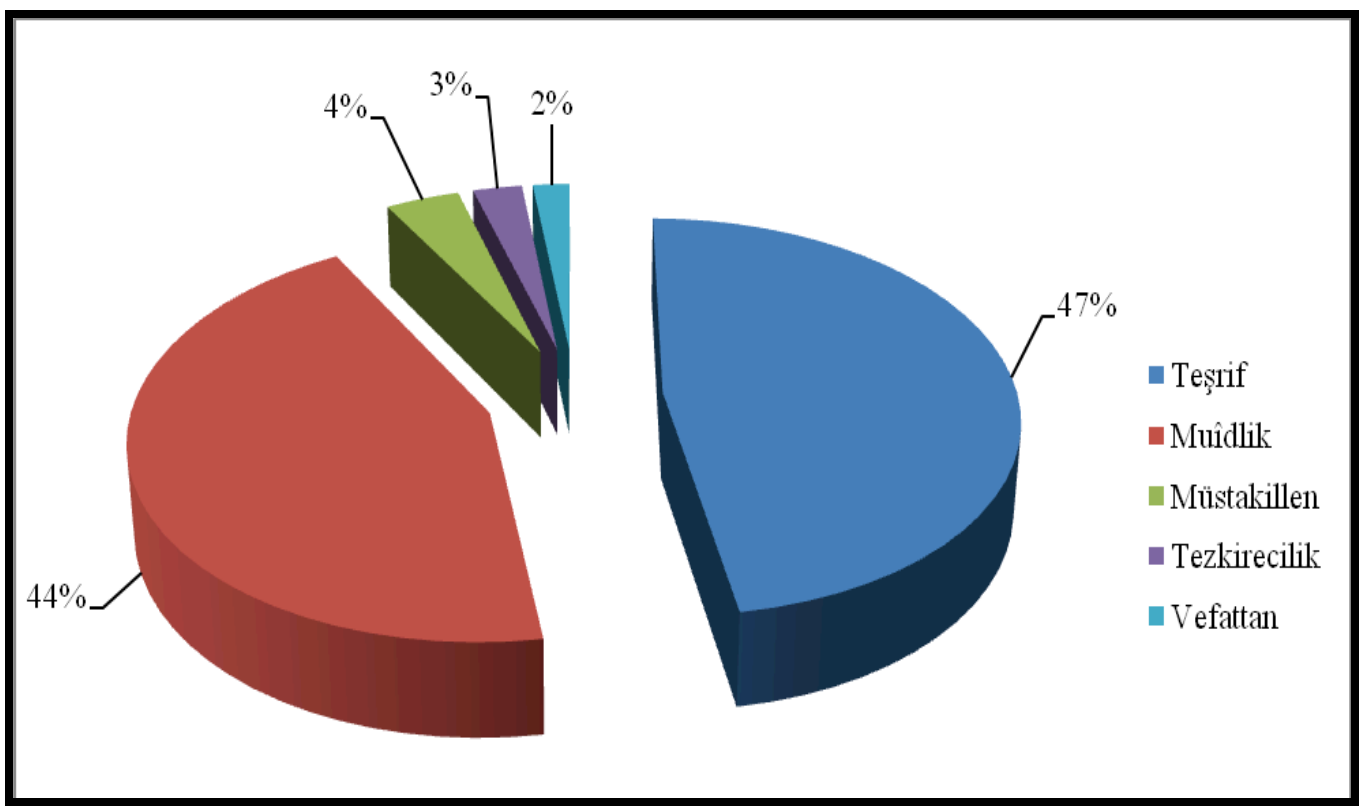

Osmanlı Devleti'nde yüksek dereceli ilmiye mensupları, bir görevden başka bir göreve tayin edildiklerinde ya da sefere katıldıklarında, kanunların kendilerine tanıdığı sayıda danişmendi mülazemet ruznamçesine yazdırma hakkına sahiptiler. Bu şekilde teşkilata giriş teşriften mülazemet olarak tanımlanmıştır. Grafik 3'e göre teşrif yoluyla ilmiye silkine dâhil olarak Bursa medreselerine atanan müderrislerin sayısı 74'tür ve incelenen dönem içinde $\% 47$ 'lik bir oran oluştururlar. Medreselerde tedris hizmetini yerine getiren müderrislerin bu faaliyetlerinde en önemli yardımcıları başarılı danişmedler arasından seçilen muîd unvanlı kişiler olmuştur. Yüksek dereceli müderrisler başka medreselere tayin edildiklerinde muîd olarak yanlarında hizmet eden öğrencilerini mülazım yazdırabilmişler ve bu yolla ilmiye teşkilatına giriş muîdlikten mülazemettir. Grafik 3'te ilk defa müderrislik faaliyetine Bursa'da başlayan 69 kişinin muîdlikten mülazım olduğu ve \%44'lük orana sahip oldukları tespit edilmiştir. Bu veriler XVII. ve XVIII. yüzyılda ilk görevlerine Bursa'da başlayan müderrislerin ağırlıklı teşrif ve muîdlikten mülazım olarak teşkilata dâhil olduklarını göstermektedir. Çalışkanlığı ile ön plana çıkan ya da bir devlet hizmetini yerine getirenler ile mevleviyet seviyesindeki ulemaya hizmet edenler arasından seçilerek müstakillen mülazemet yoluyla teşkilata girenlerin sayısı ise 6'dir. Bu grup 156 adet yeni mülazım atamalarının \%4'ünü oluşturur. Mevcut kazaskerler bürokratik işlerinde yardımcısı olan tezkirecilerini 6 ayda bir mülazım yazabilmekteydiler ve bu şekilde ilmiye silkine giriş tezkirecilikten mülazemettir. İncelenen dönem içinde bu yol ile mülazım yazıldıktan sonra Bursa'da göreve başlayanların sayıs1 4'tir. Yüksek dereceli müderrisler vefat ettiklerinde danişmedleri, vefattan mülazım olarak ruznamçeye kayıt edilmişler ve bu yolla teşkilata girdikten sonra Bursa medreselerinde görev alan müderris sayısı ise 3'tür. Osmanlı ilmiye teşkilatına girebilmenin diğer iki yolu ise 
nevbet ve fetva eminliğindendir ${ }^{35}$. İncelenen dönemde Bursa medreselerine atananlar içinde bu şekilde teşkilata girdikten sonra ilk görev yeri Bursa olan müderris yoktur.

\section{Bursa'dan Munfasıl Müderrislerin Yeni Görev Yerleri}

Osmanlı ilmiye teşkilatında kadı ve müderris olarak kazâ ve tedris hizmetlerini yerine getiren görevlerin rotasyona tabi oldukları ve görev yerlerinde belli bir süre hizmet ettikten sonra başka bir kaza veya medreseye atandıkları bilinmektedir. Kazasker ruznamçelerinde bulunan atama kayıtları bu rotasyon siteminin nasıl uygulandığını gösteren en önemli belgelerdir. XVII. ve XVIII. yüzyıl Anadolu kazasker ruznamçelerinde bulanan toplam 3777 atama kaydı içinde önceki görev yeri Bursa medreseleri olan 564 müderris ataması vardır. Bu müderrislerin Bursa'dan sonra hangi merkezlerdeki medreselerde görev aldıkları Grafik 4'te verilmiştir.

\section{Grafik 4: Bursa Munfasıllarının Yeni Görev Yerleri}

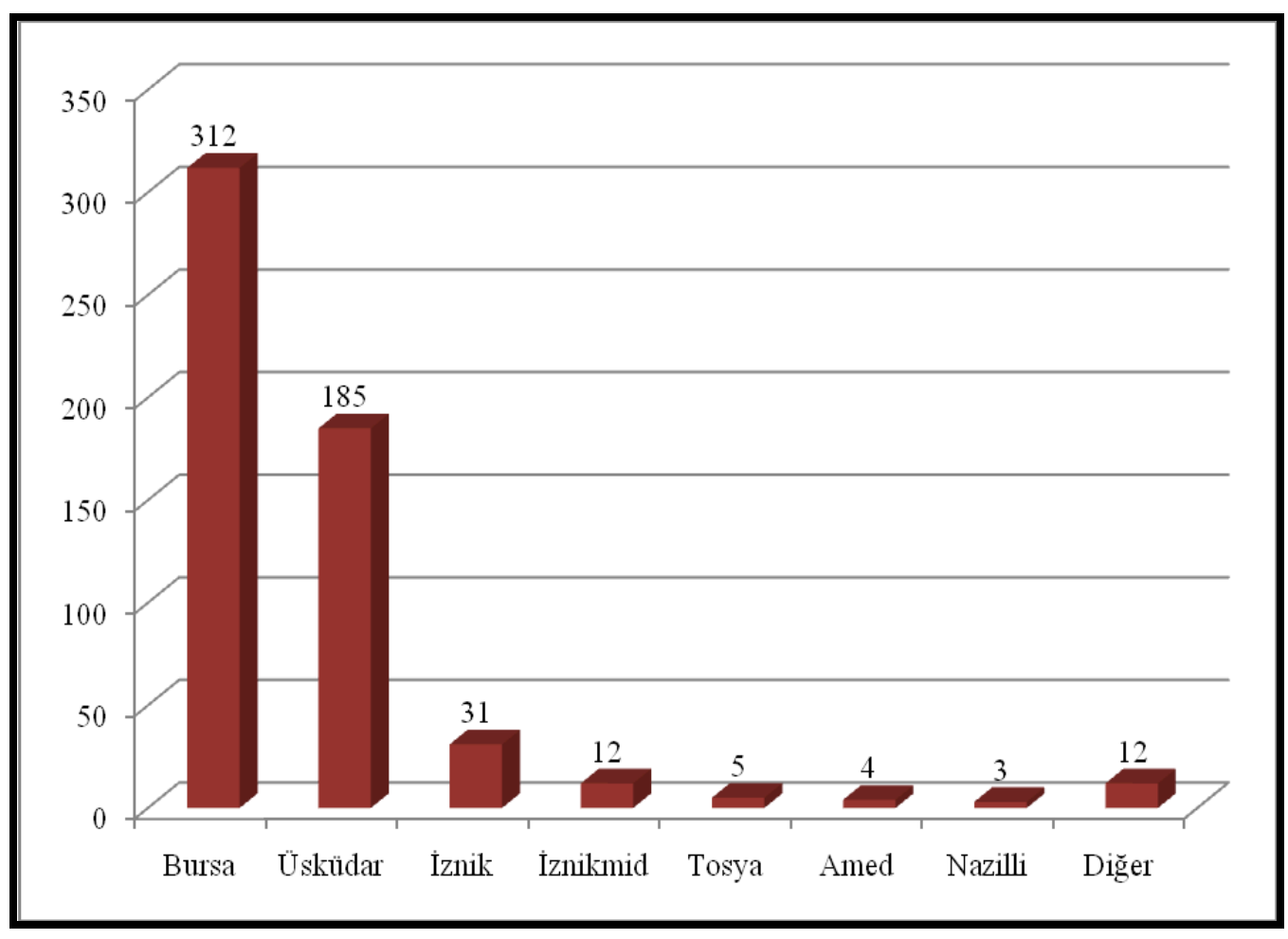

Grafik 4'e göre önceki görev yeri Bursa medreseleri olan 564 müderrisin 312'si yine Bursa'daki başka bir medreseye atanmıştır. Bu rakam \%55 oranında Bursa içi rotasyonun olduğunu gösterir. 185 müderris ise Bursa'da görev yaptıktan sonra Üsküdar'da bulunan bir medreseye atanmıştır. İki yer toplam rakamın \%88'ini oluşturur. $\mathrm{Bu}$ durum Bursa müderrislerinin ağırlıklı olarak Üsküdar ve Bursa'da bulunan başka medreselere atandıklarının gösterir. Buraların dışında Bursa'dan İznik'e 31, İznikmid'e 12, Amed'e 4, Nazilli'ye 3 müderris gitmiştir. Diğer yerler olarak gruplanan 12 müderris ise Alaşehir, Amasya, Atala,

${ }^{35}$ Beyazıt, Osmanlı İlmiye Mesleğinde İstihdam (XVI. Yüzyıl), s. 49-89.

\section{History Studies}


Kangırı, Karahisar, Kastamonu, Larende, Magnisa ve Manavgat'a gitmişler ve bu merkezlerdeki bir medresede görev yapmışlardır.

\section{Müderrislerin Gelirleri}

Müderrisler yaptıkları tedris hizmetleri karşılığında medresenin vakfı tarafından karşılanan bir ücret almışlar ve geçimlerini sağlamışlardır. Fatih Kanunnamesi yeni mülazımların ilk olarak 20 akçeyle göreve başlayacaklarını ve ilk görevlerinden sonra 5'er akçe artış ile 50 akçeye ulaşacakları hükme bağlanmıştır ${ }^{36}$. XV. yüzyılın ikinci yarısında belirlenen bu kuralın XVII. ve XVIII. yüzyıla yansımalarının en doğru ve kesin verilerini kazasker ruznamçelerinden elde etmek mümkündür. Çünkü bilindiği gibi ruznamçelere kadı ve müderrislerin görevlendirildikleri kaza ve medreselerde kaç akçe gelir elde edecekleri yazılmıştır. Bu çerçevede XVII. ve XVIII. yüzyıl Anadolu kazasker ruznamçelerinde bulunan müderris atamalarının akçe bazında dağılımı Grafik 5'te gösterilmiştir.

\section{Grafik 5: Bursa Medreselerinde Görev Alan Müderrislerin Gelirleri}

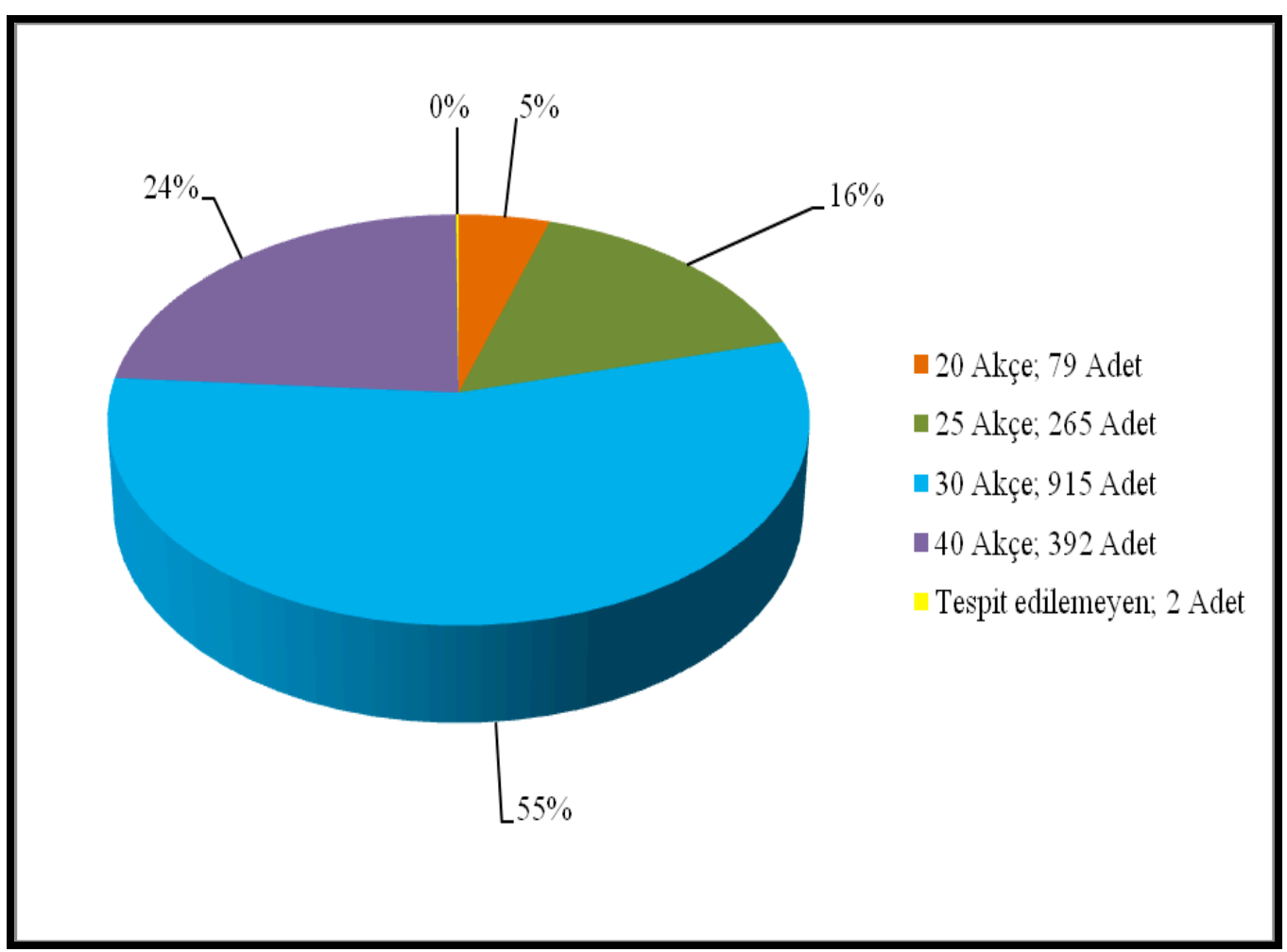

Grafiğe göre incelenen dönemde Bursa medreselerine atanan müderrislerin 79 adedi 20 akçe yevmiye ile görevlendirilmiştir. Kayıtlar incelendiğinde bu müderrislerin teşkilata yeni giren ve ilk defa bir medreseye atananlar olduğu tespit edilmiştir. Bu durum yukarıda değinilen Fatih Kanunnamesi’nde belirtildiği gibi yeni mülazımlara ödenen yevmiye miktarıdır. 25 akçe

\footnotetext{
36 "Ve ibtidâ yeni mülazım yirmi akça medreseye, andan yirmi beş, andan otuz, andan otuz beş, andan kırk, andan kırk beş, andan elli akçaya vâsıl olur..." (bk. Fatih Sultan Mehmed, Kânûnnâme-i Âl-i Osman (Tahlil ve Karşılaştırmalı Metin), Haz.Abdülkadir Özcan, s. 11).
}

\section{History Studies}


yevmiye ile atanan müderris sayısı ise $265^{\prime}$ tir. Müderrislerin 20 ve 25 akçe yevmiye aldıkları medreselerde Haşiye-i Tecrid isimli eser okutulduğu için bu isimle anılmışlardır ${ }^{37}$. Ruznamçelerde sayısal olarak en çok atama işlemi 30 akçeyle yapılmıştır. Bu rakam tüm Bursa medreselerinde görevlendirilen müderrislerin \%55'ini kapsar. Müderrislerin 30 akçe yevmiye aldıkları medreselerde Şerh-i Miftah isimli eser okutulmaktaydı ve bu grup medreseler de miftah medreseleri olarak adlandırılmıştır. Grafik 5'e göre Bursa'da en fazla miftah medreseleri vardır. Ruznamçe kayıtlarında göre XVII. ve XVIII. yüzyılda Bursa'da bulunan medreselere 40 akçe yevmiye ile atanan müderris sayısı ise 392'dir. İki adet atama kaydında ise defterin eksikliği ve defterin tahrip olması sebebiyle tespit yapılamamıştır.

Osmanlı medreselerinde görev yapan müderrislere ödenen yevmiye miktarları medresenin statüsünü değil atanan müderrisin teşkilat içindeki konumu göstermekteydi. Bu durumda aynı medreseye farklı yevmiyeler ile görevlendirilmeler yapılmıştır. Örneğin; Ahi Yakub medresesine ataması yapılan on iki müderristen bir tanesi 20 akçe yevmiye ile görevlendirilirken, üçü 25 akçe, diğer üçü 30 akçe ve kalan beş müderris ise 40 akçe yevmiyeler ile tevcîh edilmişlerdir. Ekte verilen listede Bursa medreselerine yapılan müderris atamalarının kaçar akçe ile yapıldığı medrese bazında gösterilmiştir. Tabloya göre ismi geçen medreselere $20,25,30$ ve 40 akçelik müderris tevcîhatı yapıldığ tespit edilmiştir. $\mathrm{Bu}$ medreselerden 60'ına en az bir defa 20 akçe ile görevlendirme yapılmıştır. 20 akçe ile atanan müderrislerin menşeine bakıldığında hepsinin teşkilata yeni giren ve ilk defa bir medreseye atananlar olduğu görülmektedir. Medreselerinden 117'sine en az bir defa 25 akçe yevmiye ile müderris ataması yapılmıştır. İncelenen dönem için tespit edilen medreselerin \%80'ine yani 152 'sine en az bir defa 30 akçe yevmiye ile müderris atanmıştır. Bu durum Bursa'da miftah medreselerinin çoğunlukta olduğunun göstergesidir. Daha önce değinildiği gibi Osmanlı ilmiye teşkilatında görev alan müderris ve kadıların teşkilat içindeki statüleri tecrübe ve yıla bağlı olarak değişmiş ve zamanla rütbeleri yükselmiştir. $\mathrm{Bu}$ artışın göstergesi de ilmiye mensuplarının aldıkları yemiyeler olmuştur. Böylece aynı medreseye farklı statüde müderris atanması durumunda yevmiye miktarı değişmiştir. Bu uygulama imparatorluğun Anadolu ve Rumeli canibinin her ikisi içinde geçerlidir ${ }^{38}$.

\section{Müderrislerin Kariyer Basamakları}

Osmanlı Devleti ilmiye teşkilatındaki kadı ve müderris adayları mesleki kariyerlerine en alt düzeyli medreselerden başlamışlar ve hayatları boyunca geçirdikleri rotasyon süreçleri ulemanın teşkilat içinde yükselmesini sağlamıştır. Anadolu ve Rumeli kazaskerlerinin başında bulunduğu dairelerde tutulan atama ruznamçeleri bu kariyer süreçlerini gösteren en önemli kaynaklardır. XVII. ve XVIII. yüzyıl Anadolu kazasker ruznamçelerinde yer alan kayıtlar, ataması yapılan müderrislerin eski görevlerinde aldıkları yevmiye miktarlarını ve yeni atandıkları medreselerde alacakları yevmiyeleri göstermektedir. Böylece ulemanın silk içindeki ilerleyişleri açık bir şekilde görülmektedir. Müderrislerin eski ve yeni yevmiyelerine dair veriler kullanılarak ortaya çıkan kariyer sistemi Grafik 6'da verilmiştir.

\footnotetext{
${ }^{37}$ Uzunçarşıll, Osmanlı Devletinin Illmiye Teşkilâtı, s. 19.

${ }^{38}$ Beyazıt, Osmanlı İlmiye Mesleğinde İstihdam (XVI. Yüzyıl), s. 191.
} 


\section{Grafik 6: Bursa Medreselerine Atanan Müderrislerinin Kariyer Basamakları}

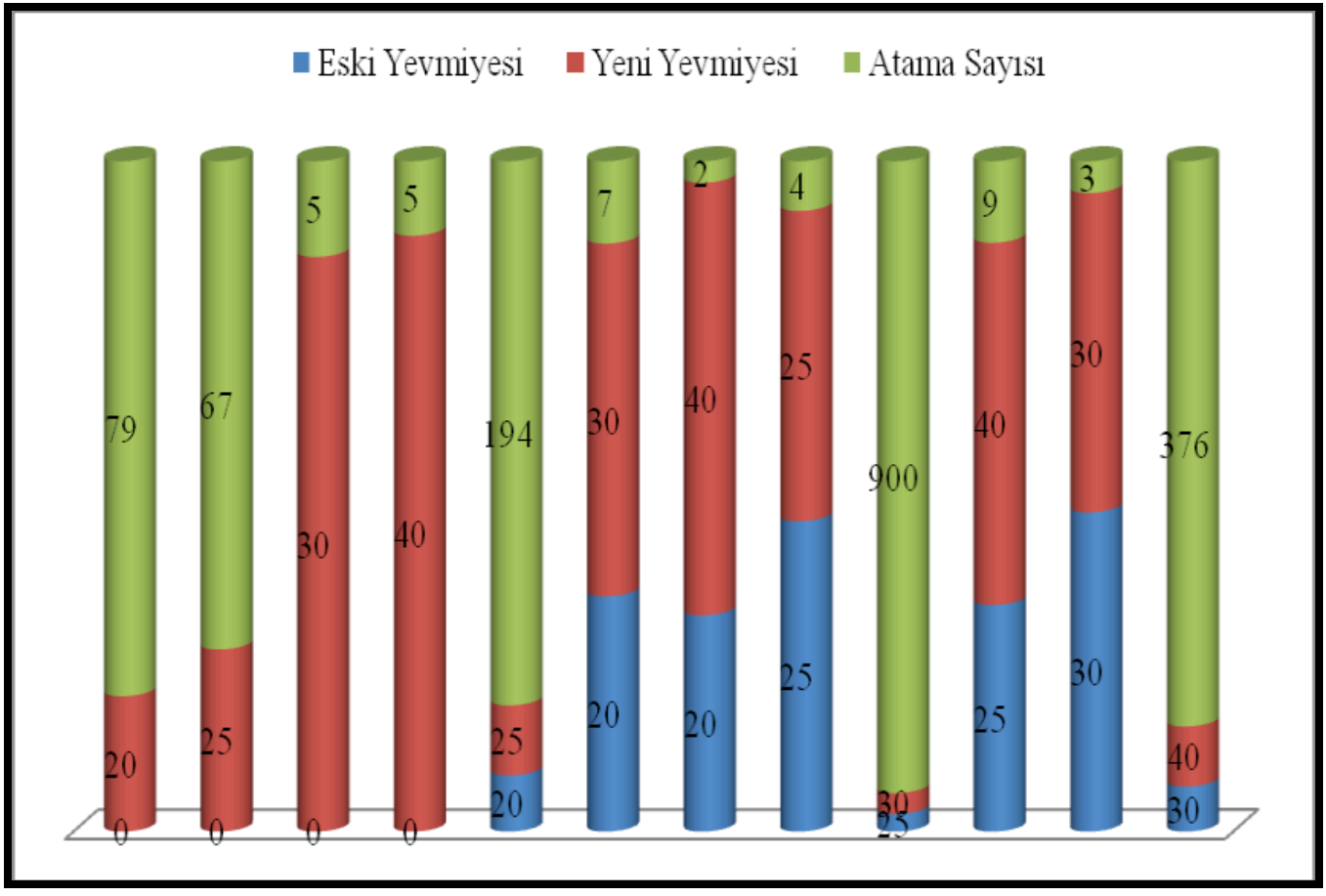

Grafik 6'ya göre; ilk dört sıradaki 156 atama kaydında eski yevmiyeleri sıfır, yeni yevmiyeleri 20, 25, 30 ve 40 akçe olarak tespit edilmiştir. Bu kayıtlar teşkilata yeni giren ve ilk defa bir medreseye görevlendirilen müderrislere dairdir. Fatih kanunnamesi yeni mülazımların 20 akçe ile göreve başlayacağı belirtmiştir ${ }^{39}$. Grafik verilerine göre bu dönemde ataması yapılan 79 yeni mülazım 20 akçe yevmiye ile görevlendirilmiştir ve bu rakam ilk defa görev alan müderrislerin \%51'ini kapsar. Yani yeni mülazımların yarısından fazlası 20 akçelik yevmiyelerle meslek hayatlarına başlamışlardır ${ }^{40}$. İlk görevlerine 20 akçenin üzerinde bir yevmiye ile başlayan müderrislerin atama kayıtları incelendiğinde bunların bir kısmının Anadolu kazaskerlik dairesinde tezkirecilik yaptıkları, bazılarının şeyhülislam ve kazaskerlerin talebeleri oldukları, bazılarının ise Mekke, Medine ve Kudüs gibi büyük kadılıklara atanan mevalinin talebeleri oldukları tespit edilmiştir. Bu şekilde 25,30 ve 40 akçelik yeni mülazım atamalarının hepsinde olmasa da bazı kayıtlara “...emsalinde cari kanunun üzere..." bilgisi düşülmüştür. $\mathrm{Bu}$ durum yüksek dereceli ulemanın talebelerinin ayrıcalıklı bir konumda olduğunun göstergesidir ${ }^{41}$.

Grafik 6'ya göre yeni mülazımların dışında kalan ve daha önce bir medresede görev yaptıktan sonra Bursa'da bulunan bir medrese atanan müderrislerin çoğunun teşkilatın kariyer sistemine uygun olarak 20 akçeden 25 akçeye, 25 akçeden 30 akçeye, 30 akçeden 40 akçeye şeklinde ilerledikleri ve kariyer basamaklarını tırmandıkları görülmektedir. Ulemanın bu tarz

\footnotetext{
${ }^{39}$ Fatih Sultan Mehmed, Kânûnnâme-i Âl-i Osman (Tahlil ve Karșılaștırmalı Metin), Haz. Abdülkadir Özcan, s. 11

${ }^{40} \mathrm{Bu}$ atama işlemlerinden bir tanesi iptal edilmiştir (bk. MA, RKR, 241/64, s. 81).

${ }^{41}$ Örnekler için (bk. MA, AKR, 435/1, vr. 27b; 439/5, vr. 33b, 34b; 436/2, vr. 43a; NOK, AKR, 5193/13, vr. 51b, 53a).
}

\section{History Studies}


ilerlemesi terakki ile hareket olarak nitelendirilmiştir. Dört atama işleminde müderrislerin eski görev yerlerinde aldıkları 25 akçe yevmiyeler ile yeni medreselerine atandıkları, üç müderrisin de eski yevmiyesi olan 30 akçe ile yeni görevine tayin edildiği görülmektedir. Misli ile hareket olarak tanımlanan bu işlemde müderrisin rütbesi yükseltilmemiştir. Grafikte yer alan 18 atamanın da teşkilatın kariyer sistemine uygun olmayarak 20 akçeden 30 akçeye ya da 25 akçeden 40 akçeye şeklinde yapıldığı tespit edilmiştir. Osmanlı ilmiye teşkilatında daha çok kadılık mesleğinde görülen ve tafra hareket olarak tanımlanan bu uygulamanın medrese atamalarında görülme sıklığı çok azdır ${ }^{42}$. Müderrisin bir veya bir kaç derece atlatılarak görevlendirilmesinde mevalizade olması ya da yüksek dereceli ulemanın talebesi olmasının etkisi vardır. Örneğin; Bursa İskender Paşa medresesinde 20 akçe yevmiye ile görev yaptıktan sonra mülazemet dönemini tamamlayarak yine Bursa'daki Abdüllatif medresesine atanan İvaz isimli müderrisin Anadolu kazaskerinin talebesi olduğu anlaş1llyor ${ }^{43}$. Yine Bursa Selimşah medresesine atanan Mehmed'in İstanbul Süleyman Paşa medresesinde 20 akçe yevmiye ile görev yaptıktan sonra şeyhülislamın işaretliyle yeni vazifesine 40 akçe ile atandığı tespit edilmiştir ${ }^{44}$.

\section{Sonuç}

XVII. ve XVIII. yüzyıl Anadolu kazasker ruznamçelerinin ana kaynak olarak kullanıldı̆̆ dönemde Anadolu kazaskerlerinin yetkisi sahasına giren Bursa medreselerine yapılan atama işlemleri üzerinden Bursa'daki medrese isimleri tespit edilmeye çalışıldı. Ruznamçelerde 191 farklı medrese isminin geçtiği tespit edildi. Bazı medreselerin isimlerinin katipler tarafından farklı şekilde yazılmasının medrese listesini kabarttığı görüldü. Ekte verilen listede mümkün mertebe farlı yazımlı aynı medreseler tespit edilmeye çalışıldı. Ruznamçelerde yer alan atama işlemlerine dair kayıtlardan sayısal veriler oluşturularak ilmiye teşkilatının istihdam süreçleri ve sistemin nasıl işlediği ortaya konulmaya çalışıldı. Ayrıca teşkilat içinde görev alan müderrislerin silk içindeki ilerleyişlerine dair bilgiler de yine çalışmanın sonuçları arasındadır. $\mathrm{Bu}$ çerçevede XVII. ve XVIII. yüzyılda Bursa medreselerine atanan müderrislerin ağırlıklı olarak İstanbul, Üsküdar ve diğer Bursa medreselerinde görev yaptıktan sonra Bursa'daki bir medreseye atandıkları, mesleğine ilk defa Bursa'daki bir medreseye atanarak başlayan yeni mülazımların \%87'sinin teşkilata muîdlik ve teşrif yoluyla dahil oldukları tespit edildi. Müderrislerin mansıbda hareketlerinin daha çok Bursa ve Üsküdar arasında geçtiği görüldü. \%55 oranın görevlendirmenin 30 akçe yevmiyeler ile yapıldı̆̆ı buna bağlı olarak kariyer geçişlerinin büyük oranda 25 akçeden 30 akçelik yevmiyeler şeklinde yapıldığı ortaya konuldu.

\footnotetext{
${ }^{42}$ Beyazıt, Osmanlı İlmiye Mesleğinde İstihdam (XVI. Yüzyıl), s. 224.

${ }^{43}$ MA, AKR, 438/4, s. 75.

${ }^{44}$ MA, AKR, 435/1, vr. 29b.
} 


\section{Kaynakça}

Arşiv Kaynakları

Bâb-ı Meşîhat Arşivi

AKR, 435/1; 436/2;437/3;438/4;439/5;441/6-1;443/8;444/9;445/10;446/11;447/12; $448 / 13 ; 452 / 17 ; 453 / 18 ; 454 / 19 ; 455 / 20 ; 456 / 21 ; 457 / 22 ; 458 / 23 ; 459 / 24 ; 460 / 25$.

RKR, 228/51;237/60;240/63;241/64

Nuruosmaniye Kütüphanesi

AKR, 5193/11; 5193/13; 5193/14; 5193/16; 5193/17; 5193/19; 5193/21; 5193/22; 5193/23; $5193 / 24 ; 5193 / 25 ; 5193 / 26 ; 5193 / 27 ; 5193 / 28 ; 5193 / 30 ; 5193 / 31 ; 5193 / 32 ; 5193 / 33$; $5193 / 34 ; 5193 / 35 ; 5193 / 36 ; 5193 / 37$.

\section{Araştırma Eserleri}

AKGÜNDÜZ, Murat, Osmanlı Medreseleri -XIX. Astr-, İstanbul 2004.

AYDIN, Bilgin, İlhami Yurdakul, İsmail Kurt, Bâb-ı Meşîhat Şeyhülislâmlık Arşivi Defter Kataloğ $u$, İSAM yay., İstanbul 2006.

AYDIN, Bilgin-Rıfat Günalan, "Ruus Defterlerine Göre XVI. Yüzyılda Osmanlı Müderrisleri”, Osmanlı'nın İzinde Prof. Dr. Mehmet Ípşirli Armă̆anı, Hz. Feridun Emecen, vd., İstanbul 2013.

BAKIR, Nuran, XVII. Asrın Ikkinci Yarısında Payeli ve Bilfiil Anadolu ve Rumeli Kazaskerleri, İstanbul Üniversitesi Edebiyat Fakültesi Tarih Bölümü, Mezuniyet Tezi, İstanbul 1966.

BALTACI, Cahit, “Kâdî-asker Rûz-nâmçeleri'nin Tarihî ve Kültürel Ehemmiyeti”, İslam Medeniyet Mecmuast, IV/1, İstanbul 1979, s. 55-100.

"The İmportence Of The Kad1 Registers For The Islamic World", Studies On Turkish-Arab Relations, II, İstanbul 1987, s. 166-169. XV-XVI. Astrlarda Osmanlı Medreseleri, İstanbul 2005.

BEYAZIT, Yasemin, "Kadasker Ruznâmçelerinde Tipoloji ve Yeterlilik”, Özer Ergenç Armă̆anı, ed. Ümit Ekin, İstanbul 2013, s. 97-112.

Osmanlı İmiye Mesleğinde İstihdam (XVI. Yüzyıl), Ankara 2014.

Kadıasker Atama Ruznâmçelerinden "Çivizâde Mehmed Efendi Ruznamçesi” Türk Tarih Kurumu Yayınları, Ankara 2018.

"Osmanlı İlmiyye Bürokrasisinde Şeyhülislâmlığın Değişen Rolü ve Mülâzemet Sistemi (XVI-XVIII. Yüzyıllar)”, Belleten, LXVIII/267, Ankara 2009, s. 423-441.

, “Osmanlı Eğitim Sistemi İçinde Buk'a Medreseleri”, Osmanlı Medreseleri: Ĕ̈itim, Yönetim ve Finans, ed. Fuat Aydın, Mahmud Zengin, vd., İstanbul 2018, s. 447-472.

BİLGE, Mustafa, Ilk Osmanlı Medreseleri, İstanbul 1984.

BOZKURT, Nebi, "Medrese”, Dİ, XXVIII, 323-327.

, "Müderris", $D \dot{I} A$, XXXI, 467-468

DEVELİĞGLU, Ferit, Osmanlıca-Türkçe Ansiklopedik Lûgat, Ankara 1997, s. 599.

ERÜNSAL, İsmail, "Nuruosmaniye Kütüphanesinde Bulunan Bazı Kazasker Ruznâmçeleri”, Ístanbul Üniveresitesi Edebiyat Fakültesi Tarih Enstitüsü Dergisi (ï̈UEFD), X-XI İstanbul 1981, s. 3-15. Osmanlı Kültür Tarihinin Bilinmeyenleri, İstanbul 2014.

Fatih Sultan Mehmed, Kânûnnâme-i Âl-i Osman (Tahlil ve Karşılaştırmalı Metin), Haz. Abdülkadir Özcan, İstanbul 2003.

GÖKÇAY, Gülsen, XVIII. Asrın İlk Yarısında Anadolu ve Rumeli Kazaskerleri, İstanbul Üniversitesi Edebiyat Fakültesi Tarih Bölümü, Mezuniyet Tezi, İstanbul 1964.

GÜL, Ahmet, Osmanlı Medreselerinde Eğitim-Öğretim ve Bunlar Arasında Dâru'l-Hadîslerin

\section{Yeri, Ankara 1997.}


HIZLI, Mefail, "Osmanlı Medreselerinde Okutulan Dersler ve Eserler", Uludağ Üniversitesi Ilahiyat Fakültesi Dergisi, XVII/1, Bursa 2008, s. 25-46.

, "Kuruluşundan Osmanlılara Kadar Medreseler", Uludağ Üniversitesi Illahiyat Fakültesi Dergisi, II/2, Bursa 1987, s. 273-281.

, Osmanlı Klasik Döneminde Bursa Medreseleri, İstanbul 1998

İHSANOĞLU, Ekmeleddin, “Osmanlı Eğitim ve Bilim Kurumları”, Osmanlı Devleti Tarihi, II, ed. Ekmeddin İhsanoğlu, IRCICA yay.,İstanbul 1994.

İNALCIK, Halil, Osmanlı Imparatorluğu Klasikçağ (1300-1600), çev. Ruşen Sezer, İstanbul Mayis 2003.

İPŞİRLİ, Mehmet, "Medrese" DIA, XXVIII, 327-333.

, "Kazasker", DIA, XXV, 140-143.

, "Müderris", $D \dot{I} A$, XXXI, 468-470.

, "Buk'a", DIA, VI, 386-387.

KAYADİBİ, Fahri, "Fatih Sultan Mehmed Döneminde Eğitim ve Bilim”, İstanbul Üniversitesi Illahiyat Fakültesi Dergisi, VIII, İstanbul 2003, s. 1-18.

Koçi Bey Risaleleri, haz. Seda Çakmakçıŏglu, İstanbul 2008, s. 46-47.

KURU, Levent, Kazasker Ruznamçelerine Göre 18. Yüzyllın İlk Yarısında Rumeli'de Kadılık Müessesesi, Marmara Üniversitesi Türkiyat Araştırmaları Enstitüsü, Doktora Tezi, İstanbul 2016.

ORTAYLI, İlber, Hukuk ve İdare Adamı Olarak Osmanlı Devletinde Kadı, Ankara 1994. , Türkiye Teşkilât ve İdare Tarihi, Ankara 2007

ÖZERGIN, M. Kemal,“Eski Bir Rûznâme'ye Göre İstanbul ve Rumeli Medreseleri”, İstanbul Üniveresitesi Edebiyat Fakültesi Tarih Enstitüsü Dergisi (IÜEFD), IV-V, İstanbul 1974, s. 263-290.

TAŞDEMİRCI, Ersoy, "Osmanlı İmparatorluğu'nda Medreseler”, Erciyes Üniversitesi Sosyal Bilimler Enstitüsü Dergisi, III, Kayseri 1989, s. 519-532.

ULUSOY, Ahmet, Kuruluşundan 17. Yüzyıla Kadar Osmanlı Medreselerinde Eğitim-Öğretim Faaliyetleri, Selçuk Üniversitesi Sosyal Bilimler Enstitüsü Yüksek Lisans Tezi, Konya 2007.

UNAN, Fahri, "Osmanlı İlmiye Tarîkinde "Pâye"li Tâyinler Yahut Devlete Kazanç Kapısı, Belleten, LXII/233, Ankara 1998, s. 42-64.

UZUNÇARŞILI, İ.H, Osmanlı Devletinin İlmiye Teşkilâtı, Ankara 1988.

ÜNAL, Mehmet Ali, Osmanlı Müesseseleri Tarihi, Isparta 2002. 

Ek: XVII. ve XVIII. Yüzyılda Bursa Medreselerine Yapılan Atama Sayıları ve
Müderrislerin Yevmiyeleri ${ }^{45}$

\begin{tabular}{|c|c|c|c|c|c|c|}
\hline $\begin{array}{c}\text { Sira } \\
\text { Numarası }\end{array}$ & Medrese İsmi & $\begin{array}{c}\text { Atama } \\
\text { Sayısı }\end{array}$ & $\begin{array}{c}20 \\
\text { Akçe }\end{array}$ & $\begin{array}{c}25 \\
\text { Akçe }\end{array}$ & $\begin{array}{c}30 \\
\text { Akçe }\end{array}$ & $\begin{array}{c}40 \\
\text { Akçe }\end{array}$ \\
\hline 1 & Abbas Ağa & 4 & $\mathrm{x}$ & $\mathrm{x}$ & $\mathrm{x}$ & $\mathrm{x}$ \\
\hline 2 & Abdülkerim $^{46}$ & 5 & $\mathrm{x}$ & & $\mathrm{x}$ & $\mathrm{x}$ \\
\hline 3 & Abdülkerim Çavuş & 4 & & & $\mathrm{x}$ & \\
\hline 4 & Abdüllatif & 5 & & $\mathrm{x}$ & $\mathrm{x}$ & $\mathrm{x}$ \\
\hline 5 & Ahi Yakub & 12 & $\mathrm{x}$ & $\mathrm{x}$ & $\mathrm{x}$ & $\mathrm{x}$ \\
\hline 6 & Ahmed Ağa ${ }^{47}$ & 1 & & & $\mathrm{x}$ & \\
\hline 7 & Ahmed Bey & 5 & $\mathrm{x}$ & & $\mathrm{x}$ & $\mathrm{x}$ \\
\hline 8 & Ahmed Efendi & 14 & & & $\mathrm{x}$ & $\mathrm{x}$ \\
\hline 9 & Ahmed Gazi & 3 & $\mathrm{x}$ & & & $\mathrm{x}$ \\
\hline 10 & Ahmed Paşa & 7 & & $\mathrm{x}$ & $\mathrm{x}$ & $\mathrm{x}$ \\
\hline 11 & Ak Mehmed Paşa & 2 & & $\mathrm{x}$ & & $\mathrm{x}$ \\
\hline 12 & Ali Bey & 3 & $\mathrm{x}$ & $\mathrm{x}$ & & \\
\hline 13 & Ali Paşa & 7 & & & $\mathrm{x}$ & $\mathrm{x}$ \\
\hline 14 & Ali Paşa-yı Atik & 3 & & & $\mathrm{x}$ & $\mathrm{x}$ \\
\hline 15 & Arabiye & 3 & $\mathrm{x}$ & $\mathrm{x}$ & $\mathrm{x}$ & \\
\hline
\end{tabular}

\footnotetext{
${ }^{45} \mathrm{Bu}$ tabloda ismi geçen medrese isimleri Anadolu kazaskerliği tarafından XVII. ve XVIII. yüzyılda tutulmuş ruznamçelerdeki atama kayıtlarından çıkarılmıştır ve listede toplam 191 medrese vardır. Ancak bazı medreselerin isimlerinin kâtipler tarafından farklı şekillerde yazılmasının listedeki medrese sayısını arttırdığı anlaşılmaktadır. Biz tespit edebildiğimiz aynı medreseleri göstermeye çalıştık. Bunun yanına listenin diğer bir problemi ruznamçelere Bursa medresesi olarak kaydedilen ancak durumu şüpheli olan medreselerdir. Bunlarla ilgili de dipnot yoluyla açıklamalar yapıldı.

${ }^{46}$ Listede "Abdülkerim" ismiyle üç medrese vardır. "Seyyid Abdülkerim” ve "Abdülkerim Çavuş" dışında bir de unvan olmadan sadece "Abdülkerim" olarak yazılmış. Bunların aynı medrese olma ihtimaller vardır.

${ }^{47}$ İncelenen dönemdeki ruznamçelerde adı bir kez geçen bu medreseyle aynı ismi taşıyan İstanbul ve Üsküdar'da iki medrese vardır. Kâtip burada "Ağg”" unvanı konusunda ya da yer konusun bir hata yapmış olabilir.
}

\section{History Studies}


Levent Kuru

\begin{tabular}{|c|c|c|c|c|c|c|c|}
\hline & $\begin{array}{c}\text { Sira } \\
\text { Numarası }\end{array}$ & Medrese İsmi & $\begin{array}{c}\text { Atama } \\
\text { Sayısı }\end{array}$ & $\begin{array}{c}20 \\
\text { Akçe }\end{array}$ & $\begin{array}{c}25 \\
\text { Akçe }\end{array}$ & $\begin{array}{c}30 \\
\text { Akçe }\end{array}$ & $\begin{array}{c}40 \\
\text { Akçe }\end{array}$ \\
\hline & 16 & Arizi Çelebi & 6 & $\mathrm{x}$ & $\mathrm{x}$ & $\mathrm{x}$ & $\mathrm{x}$ \\
\hline & 17 & Aydın Bey & 1 & & $\mathrm{x}$ & & \\
\hline & 18 & Aydın Paşa & 23 & & $\mathrm{x}$ & $\mathrm{x}$ & $\mathrm{x}$ \\
\hline & 19 & Baba Efendi & 30 & $\mathrm{x}$ & $\mathrm{x}$ & $\mathrm{x}$ & $\mathrm{x}$ \\
\hline & 20 & Bahâeddin & 29 & & $\mathrm{x}$ & $\mathrm{x}$ & $\mathrm{x}$ \\
\hline & 21 & Bali Paşa & 1 & & & $\mathrm{x}$ & \\
\hline & 22 & Başçı İbrahim & 4 & & & $\mathrm{x}$ & $\mathrm{x}$ \\
\hline & 23 & Bayezid $\mathrm{Han}^{48}$ & 68 & $\mathrm{x}$ & $\mathrm{x}$ & $\mathrm{x}$ & $\mathrm{x}$ \\
\hline$\frac{\text { HISTORY }}{\text { STUDIES }}$ & 24 & Bayezid Paşa & 13 & $\mathrm{x}$ & $\mathrm{x}$ & $\mathrm{x}$ & $\mathrm{x}$ \\
\hline 1051 & 25 & Bayram Ağa & 2 & & & $\mathrm{x}$ & \\
\hline & 26 & Bayram Çelebi & 1 & $\mathrm{x}$ & & & \\
\hline $\begin{array}{l}\text { Issue } 3 \\
\text { June }\end{array}$ & 27 & Bayram Kethüda $^{49}$ & 1 & & $\mathrm{x}$ & & \\
\hline & 28 & Behmen Ağa & 11 & & $\mathrm{x}$ & $\mathrm{x}$ & $\mathrm{x}$ \\
\hline & 29 & Behram Kethüda $^{50}$ & 1 & & & & $\mathrm{x}$ \\
\hline & 30 & Beşirzâde & 24 & & $\mathrm{x}$ & $\mathrm{x}$ & $\mathrm{x}$ \\
\hline & 31 & Beşli & 1 & & & $\mathrm{x}$ & \\
\hline & 32 & Caberiyye & 8 & $\mathrm{x}$ & $\mathrm{x}$ & $\mathrm{x}$ & $\mathrm{x}$ \\
\hline & 33 & Cafer Ağa & 4 & & $\mathrm{x}$ & $\mathrm{x}$ & $\mathrm{x}$ \\
\hline & 34 & Cafer Paşa & 12 & & $\mathrm{x}$ & $\mathrm{x}$ & $\mathrm{x}$ \\
\hline & 35 & Cana'lemzâde & 25 & $\mathrm{x}$ & $\mathrm{x}$ & $\mathrm{x}$ & $\mathrm{x}$ \\
\hline & 36 & Canbaziyye & 2 & & $\mathrm{x}$ & & $\mathrm{x}$ \\
\hline
\end{tabular}

${ }^{48} \mathrm{Bu}$ medresenin ruznamçelerde; Bayezid Han, Yıldırım, Yıldırım Bayezid Han olarak üç farklı yazımı vardır. Listeye de bu şekilde geçildi (bk. sıra: 23, 188, 189).

49 Üsküdar medresesi

${ }^{50}$ Üsküdar medresesi 
XVII. ve XVIII. Yüzyıllarda Bursa Medreseleri ve Müderris Tevcîhatı

\begin{tabular}{|c|c|c|c|c|c|c|}
\hline $\begin{array}{c}\text { Sira } \\
\text { Numarası }\end{array}$ & Medrese İsmi & $\begin{array}{c}\text { Atama } \\
\text { Sayısı }\end{array}$ & $\begin{array}{c}20 \\
\text { Akçe }\end{array}$ & $\begin{array}{c}25 \\
\text { Akçe }\end{array}$ & $\begin{array}{c}30 \\
\text { Akçe }\end{array}$ & $\begin{array}{c}40 \\
\text { Akçe }\end{array}$ \\
\hline 37 & Cevheriyye & 13 & $\mathrm{x}$ & & $\mathrm{x}$ & $\mathrm{x}$ \\
\hline 38 & Çakmakıyye & 1 & & & $\mathrm{x}$ & \\
\hline 39 & Davud Ağa & 1 & & & $\mathrm{x}$ & \\
\hline 40 & Defterdar Paşa & 7 & & $\mathrm{x}$ & $\mathrm{x}$ & $\mathrm{x}$ \\
\hline 41 & Durmuş Efendi & 2 & $\mathrm{x}$ & & $\mathrm{x}$ & \\
\hline 42 & Ebri Bey & 6 & & $\mathrm{x}$ & $\mathrm{x}$ & \\
\hline 43 & Ebu Ali & 2 & $\mathrm{x}$ & & & $\mathrm{x}$ \\
\hline 44 & Efdal Efendi & 37 & $\mathrm{x}$ & $\mathrm{x}$ & $\mathrm{x}$ & $\mathrm{x}$ \\
\hline 45 & Efdalzâde $^{51}$ & 1 & & & $\mathrm{X}$ & \\
\hline 46 & el-Hac Hasan & 2 & & & $\mathrm{X}$ & \\
\hline 47 & el-Hac Murad ${ }^{52}$ & 4 & $\mathrm{x}$ & $\mathrm{x}$ & $\mathrm{X}$ & \\
\hline 48 & el-Hac Rüstem ${ }^{53}$ & 5 & & $\mathrm{x}$ & $\mathrm{X}$ & $\mathrm{x}$ \\
\hline 49 & Emin Bey & 10 & & $\mathrm{x}$ & $\mathrm{X}$ & $\mathrm{x}$ \\
\hline 50 & Erzincani & 3 & & $\mathrm{x}$ & $\mathrm{X}$ & \\
\hline 51 & Esediye & 48 & $\mathrm{x}$ & $\mathrm{x}$ & $\mathrm{x}$ & $\mathrm{x}$ \\
\hline 52 & Eyüb Paşa & 14 & & $\mathrm{x}$ & $\mathrm{x}$ & $\mathrm{x}$ \\
\hline 53 & Fahreddin Paşa & 5 & & & $\mathrm{x}$ & \\
\hline 54 & Fahri Bey $^{54}$ & 1 & & & $\mathrm{x}$ & \\
\hline 55 & Fahriye & 10 & $\mathrm{x}$ & $\mathrm{x}$ & $\mathrm{x}$ & \\
\hline 56 & Faik Paşa & 9 & & $\mathrm{X}$ & $\mathrm{x}$ & $\mathrm{X}$ \\
\hline
\end{tabular}

51 Atama kaydında "Efdalzâde" olarak geçen medresenin "Efdal Efendi” olması muhtemeldir. Çünkü Efdalzâde medresesi İstanbul'dadir.

${ }^{52}$ Listede 72. sıradaki "Hacı Murad” medresesiyle aynı yer.

${ }^{53}$ Listede 73. sıradaki "Hacı Rüstem" medresesiyle aynı yer.

54 "Fahriye” medresesi olması muhtemeldir. Çünkü “Fahri Bey” medresesi Üsküdar'dadır.

\section{History Studies}


Levent Kuru

\begin{tabular}{|c|c|c|c|c|c|c|c|}
\hline & $\begin{array}{c}\text { Sira } \\
\text { Numarası }\end{array}$ & Medrese İsmi & $\begin{array}{c}\text { Atama } \\
\text { Sayısı }\end{array}$ & $\begin{array}{c}20 \\
\text { Akçe }\end{array}$ & $\begin{array}{c}25 \\
\text { Akçe }\end{array}$ & $\begin{array}{c}30 \\
\text { Akçe }\end{array}$ & $\begin{array}{c}40 \\
\text { Akçe }\end{array}$ \\
\hline & 57 & Fazlı Efendi & 3 & & & $\mathrm{x}$ & \\
\hline & 58 & Fazullah Efendi & 4 & & $\mathrm{x}$ & $\mathrm{x}$ & $\mathrm{x}$ \\
\hline & 59 & Ferhad Paşa & 11 & & $\mathrm{x}$ & $\mathrm{x}$ & $\mathrm{x}$ \\
\hline & 60 & Ferhâdiye & 5 & & & $\mathrm{x}$ & $\mathrm{x}$ \\
\hline & 61 & Ferruh Ağa & 10 & $\mathrm{x}$ & $\mathrm{x}$ & $\mathrm{x}$ & $\mathrm{x}$ \\
\hline & 62 & Ferruh Paşa & 17 & & $\mathrm{x}$ & $\mathrm{x}$ & $\mathrm{x}$ \\
\hline & 63 & Fethi Bey & 4 & $\mathrm{x}$ & $\mathrm{x}$ & & $\mathrm{x}$ \\
\hline & 64 & Fethiye & 14 & & & $\mathrm{x}$ & $\mathrm{x}$ \\
\hline$\frac{\text { HISTORY }}{\text { STUDIES }}$ & 65 & Firuz A ğa & 17 & $\mathrm{x}$ & $\mathrm{x}$ & $\mathrm{x}$ & \\
\hline 1053 & 66 & Gazi Hüdâvendigâr & 6 & & & $\mathrm{x}$ & \\
\hline & 67 & Gökdere & 5 & & $\mathrm{x}$ & $\mathrm{x}$ & $\mathrm{x}$ \\
\hline $\begin{array}{l}\text { Issue } 3 \\
\text { June }\end{array}$ & 68 & Gülfam & 6 & & & $\mathrm{x}$ & $\mathrm{x}$ \\
\hline & 69 & Gülşenîzâde & 2 & $\mathrm{x}$ & & $\mathrm{x}$ & \\
\hline & 70 & Gümüşizâde & 14 & $\mathrm{x}$ & $\mathrm{x}$ & & $\mathrm{x}$ \\
\hline & 71 & Güzelce Hasan & 9 & & $\mathrm{x}$ & $\mathrm{x}$ & $\mathrm{x}$ \\
\hline & 72 & Hacı Murad & 3 & & $\mathrm{x}$ & & $\mathrm{x}$ \\
\hline & 73 & Hacı Rüstem & 3 & $\mathrm{x}$ & & $\mathrm{x}$ & \\
\hline & 74 & Halil Paşa & 16 & $\mathrm{x}$ & $\mathrm{x}$ & $\mathrm{x}$ & \\
\hline & 75 & Halisi Efendi & 4 & & $\mathrm{x}$ & $\mathrm{x}$ & $\mathrm{x}$ \\
\hline & 76 & Hamza Çavuş & 3 & & & $\mathrm{x}$ & \\
\hline & 77 & Hanceriye & 4 & & $\mathrm{x}$ & $\mathrm{x}$ & $\mathrm{x}$ \\
\hline & 78 & Hasan Paşa & 25 & & $\mathrm{x}$ & $\mathrm{x}$ & $\mathrm{x}$ \\
\hline & 79 & Hasan Paşa-yı Atik & 8 & & $\mathrm{x}$ & $\mathrm{x}$ & $\mathrm{x}$ \\
\hline
\end{tabular}


XVII. ve XVIII. Yüzyıllarda Bursa Medreseleri ve Müderris Tevcîhatı

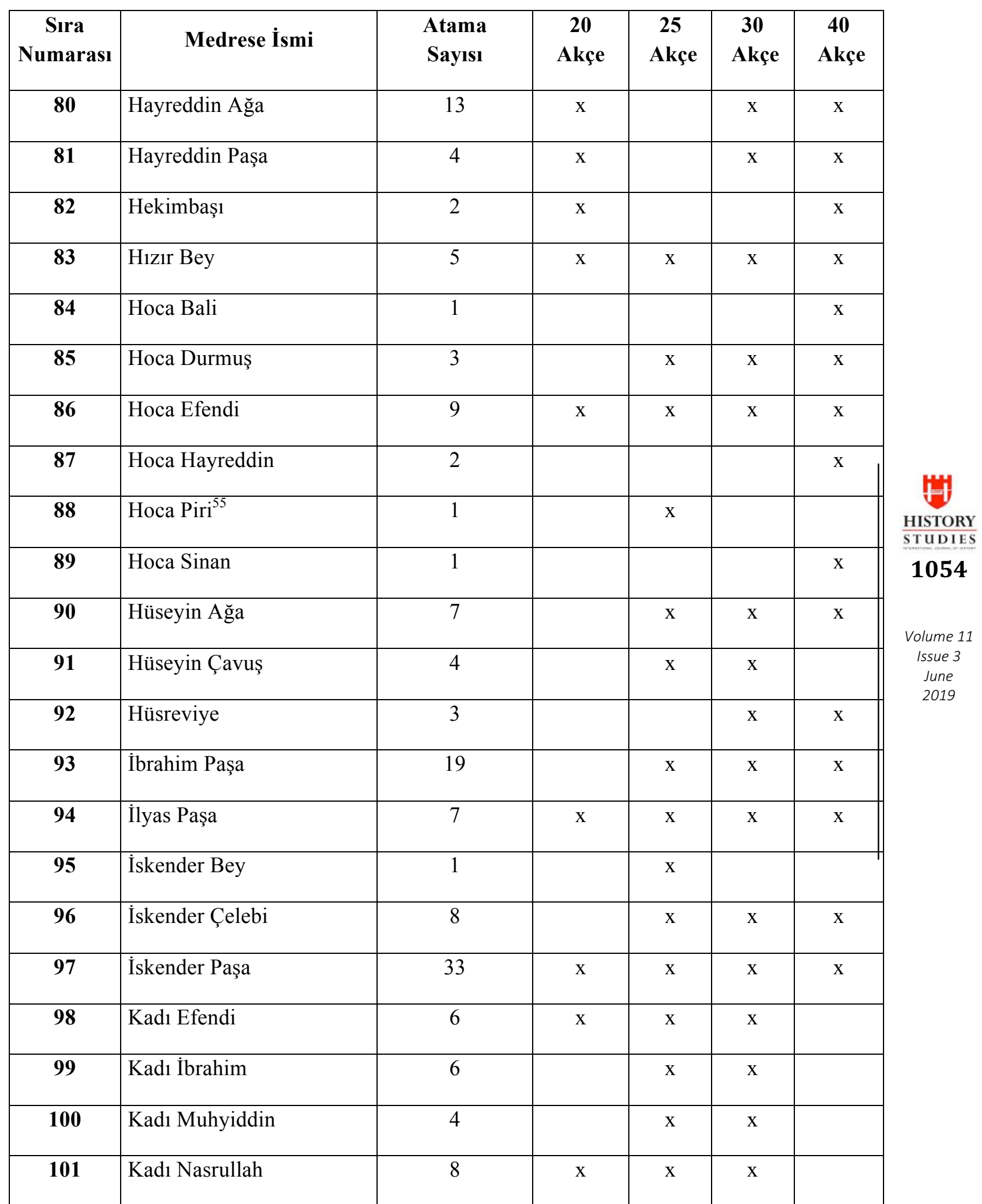

\footnotetext{
${ }^{55} \mathrm{Bu}$ medreseye yapılan iki atama işlemi vardır. Birisinde "Hoca Piri" olarak yazılırken diğerinde "Piri Hoca" yazılmıştır (bk.sıra:144).
} 
Levent Kuru

\begin{tabular}{|c|c|c|c|c|c|c|c|}
\hline & $\begin{array}{c}\text { Sira } \\
\text { Numarası }\end{array}$ & Medrese İsmi & $\begin{array}{c}\text { Atama } \\
\text { Sayısı }\end{array}$ & $\begin{array}{c}20 \\
\text { Akçe }\end{array}$ & $\begin{array}{c}25 \\
\text { Akçe }\end{array}$ & $\begin{array}{c}30 \\
\text { Akçe }\end{array}$ & $\begin{array}{c}40 \\
\text { Akçe }\end{array}$ \\
\hline & 102 & Kalender Paşa & 1 & & & & $\mathrm{x}$ \\
\hline & 103 & Kameriye & 6 & & $\mathrm{x}$ & $\mathrm{x}$ & \\
\hline & 104 & Kara Kadı & 2 & & $\mathrm{x}$ & $\mathrm{x}$ & \\
\hline & 105 & Kasım Paşa & 1 & & & & $\mathrm{x}$ \\
\hline & 106 & Kerim Çavuş & 6 & & & $\mathrm{x}$ & $\mathrm{x}$ \\
\hline & 107 & Köseler & 2 & & $\mathrm{x}$ & $\mathrm{x}$ & \\
\hline & 108 & Lali Efendi & 6 & & $\mathrm{x}$ & $\mathrm{x}$ & $\mathrm{x}$ \\
\hline & 109 & Lalizâde $^{56}$ & 1 & & & $\mathrm{x}$ & \\
\hline $\begin{array}{l}\text { HISTORY } \\
\text { STUDIES }\end{array}$ & 110 & Lami Çelebi & 84 & $\mathrm{x}$ & $\mathrm{x}$ & $\mathrm{x}$ & $\mathrm{x}$ \\
\hline 1055 & 111 & Leysi Efendi $^{57}$ & 1 & & & & $\mathrm{x}$ \\
\hline & 112 & Leysizâde & 6 & & $\mathrm{x}$ & $\mathrm{x}$ & $\mathrm{x}$ \\
\hline $\begin{array}{l}\text { Issue } 3 \\
\text { June }\end{array}$ & 113 & Mahmud Ağa & 4 & & $\mathrm{x}$ & & $\mathrm{x}$ \\
\hline & 114 & Mahmud Bey & 11 & $\mathrm{x}$ & $\mathrm{x}$ & $\mathrm{x}$ & $\mathrm{x}$ \\
\hline & 115 & Mahmud Paşa & 8 & $\mathrm{x}$ & & $\mathrm{x}$ & $\mathrm{x}$ \\
\hline & 116 & Mehdiyye & 2 & & & & $\mathrm{x}$ \\
\hline & 117 & Mehmaselam & 26 & & $\mathrm{x}$ & $\mathrm{x}$ & $\mathrm{x}$ \\
\hline & 118 & Mehmed Bey & 2 & & $\mathrm{x}$ & & \\
\hline & 119 & Mehmed Paşa & 18 & $\mathrm{x}$ & $\mathrm{x}$ & $\mathrm{x}$ & $\mathrm{x}$ \\
\hline & 120 & Menla Aş1ki ${ }^{58}$ & 9 & & & $\mathrm{x}$ & $\mathrm{x}$ \\
\hline & 121 & Menla Hüseyin ${ }^{59}$ & 6 & & $\mathrm{x}$ & $\mathrm{x}$ & $\mathrm{x}$ \\
\hline & 122 & Menla-yı Atik & 4 & & & $\mathrm{x}$ & $\mathrm{x}$ \\
\hline
\end{tabular}

56 "Lali Efendi" medresesiyle aynı yer olması muhtemeldir.

57 "Leysizâde" medresesiyle aynı yer olması muhtemeldir.

58 "Molla Aşiki" medresesiyle aynı yerdir. Ruznamçelerde iki şekilde de geçmektedir (bk. sıra: 125).

59 “Molla Hüseyin” medresesiyle aynı yerdir (bk. sıra: 127). 
XVII. ve XVIII. Yüzyıllarda Bursa Medreseleri ve Müderris Tevcîhatı

\begin{tabular}{|c|c|c|c|c|c|c|}
\hline $\begin{array}{c}\text { Sira } \\
\text { Numarası }\end{array}$ & Medrese İsmi & $\begin{array}{c}\text { Atama } \\
\text { Sayısı }\end{array}$ & $\begin{array}{c}20 \\
\text { Akçe }\end{array}$ & $\begin{array}{c}25 \\
\text { Akçe }\end{array}$ & $\begin{array}{c}30 \\
\text { Akçe }\end{array}$ & $\begin{array}{c}40 \\
\text { Akçe }\end{array}$ \\
\hline 123 & Mihmaniye & 22 & & $\mathrm{x}$ & $\mathrm{x}$ & $\mathrm{x}$ \\
\hline 124 & Mimariye & 1 & & & $\mathrm{x}$ & \\
\hline 125 & Molla Aşıki & 23 & $\mathrm{x}$ & $\mathrm{x}$ & $\mathrm{x}$ & $\mathrm{x}$ \\
\hline 126 & Molla Fenari & 7 & & $\mathrm{x}$ & $\mathrm{x}$ & $\mathrm{x}$ \\
\hline 127 & Molla Hüseyin & 11 & $\mathrm{x}$ & $\mathrm{x}$ & $\mathrm{x}$ & $\mathrm{x}$ \\
\hline 128 & Molla Hüsrev & 1 & & & $\mathrm{x}$ & \\
\hline 129 & Muhyiddin & 6 & & $\mathrm{x}$ & $\mathrm{x}$ & \\
\hline 130 & Murad Paşa & 4 & & & $\mathrm{x}$ & $\mathrm{x}$ \\
\hline 131 & Muradiye & 9 & & & $\mathrm{x}$ & $\mathrm{x}$ \\
\hline 132 & Müsli Paşa & 1 & & & & $\mathrm{x}$ \\
\hline 133 & Nişancı Paşa & 1 & & & $\mathrm{x}$ & \\
\hline 134 & Niğmeti Çelebi & 61 & $\mathrm{x}$ & $\mathrm{x}$ & $\mathrm{x}$ & $\mathrm{x}$ \\
\hline 135 & Nuh Paşa & 5 & & $\mathrm{x}$ & $\mathrm{x}$ & $\mathrm{x}$ \\
\hline 136 & Nuri Efendi & 8 & & $\mathrm{x}$ & $\mathrm{x}$ & $\mathrm{x}$ \\
\hline 137 & Nurullah Efendi & 11 & $\mathrm{x}$ & $\mathrm{x}$ & $\mathrm{x}$ & $\mathrm{x}$ \\
\hline 138 & Nusret Paşa & 47 & & $\mathrm{x}$ & $\mathrm{x}$ & $\mathrm{x}$ \\
\hline 139 & Peri Peyker & 15 & & $\mathrm{x}$ & $\mathrm{x}$ & $\mathrm{x}$ \\
\hline 140 & Pervane Bey & 5 & $\mathrm{x}$ & $\mathrm{x}$ & $\mathrm{x}$ & $\mathrm{x}$ \\
\hline 141 & Perviz Bey & 1 & & $\mathrm{x}$ & & \\
\hline 142 & Pınarbaşı & 3 & & & $\mathrm{x}$ & $\mathrm{x}$ \\
\hline 143 & Piri Bey & 10 & $\mathrm{x}$ & $\mathrm{x}$ & $\mathrm{x}$ & $\mathrm{x}$ \\
\hline 144 & Piri Hoca & 1 & $\mathrm{x}$ & & & \\
\hline 145 & Piri Paşa & 10 & $\mathrm{x}$ & $\mathrm{x}$ & $\mathrm{x}$ & $\mathrm{x}$ \\
\hline
\end{tabular}


Levent Kuru

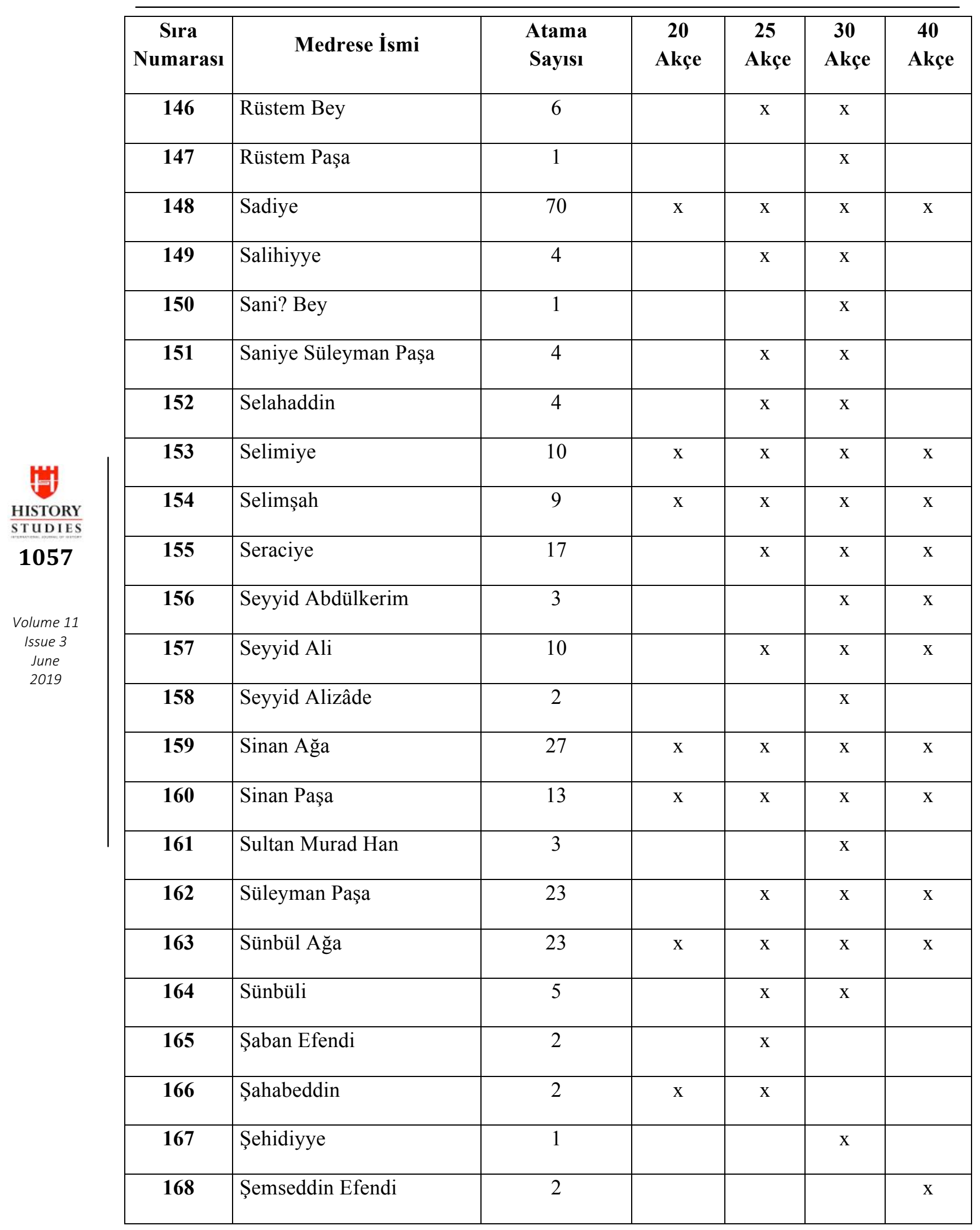


XVII. ve XVIII. Yüzyıllarda Bursa Medreseleri ve Müderris Tevcîhatı

\begin{tabular}{|c|c|c|c|c|c|c|}
\hline $\begin{array}{c}\text { Sira } \\
\text { Numarası }\end{array}$ & Medrese İsmi & $\begin{array}{c}\text { Atama } \\
\text { Sayısı }\end{array}$ & $\begin{array}{c}20 \\
\text { Akçe }\end{array}$ & $\begin{array}{c}25 \\
\text { Akçe }\end{array}$ & $\begin{array}{c}30 \\
\text { Akçe }\end{array}$ & $\begin{array}{c}40 \\
\text { Akçe }\end{array}$ \\
\hline 169 & Şerif Ahmed & 3 & & $\mathrm{x}$ & $\mathrm{x}$ & \\
\hline 170 & Şeyh Hasan & 1 & & $\mathrm{x}$ & & \\
\hline 171 & Şeyhü'l-Harem & 3 & & & $\mathrm{x}$ & $\mathrm{x}$ \\
\hline 172 & Taceddin & 1 & & & $\mathrm{x}$ & \\
\hline 173 & Taceddinzâde & 2 & & & $\mathrm{x}$ & $\mathrm{x}$ \\
\hline 174 & Tacü'l-vezir & 2 & & $\mathrm{x}$ & & \\
\hline 175 & Taczâde & 8 & $\mathrm{x}$ & $\mathrm{x}$ & $\mathrm{x}$ & $\mathrm{x}$ \\
\hline 176 & Tahmasiyye & 2 & & & $\mathrm{x}$ & \\
\hline 177 & Timuriye & 5 & $\mathrm{x}$ & $\mathrm{x}$ & $\mathrm{x}$ & $\mathrm{x}$ \\
\hline 178 & Turhan Bey & 5 & & & $\mathrm{x}$ & $\mathrm{x}$ \\
\hline 179 & Turmuş Bey & 1 & & & & $\mathrm{x}$ \\
\hline 180 & Tursunzâde & 2 & & $\mathrm{x}$ & & \\
\hline 181 & Vâiziye & 16 & $\mathrm{x}$ & $\mathrm{x}$ & $\mathrm{x}$ & $\mathrm{x}$ \\
\hline 182 & Veli Çelebi & 1 & & $\mathrm{x}$ & & \\
\hline 183 & Veliyüddin & 1 & & & & $\mathrm{x}$ \\
\hline 184 & Yakub Bey & 2 & & $\mathrm{x}$ & & $\mathrm{x}$ \\
\hline 185 & Yakub Paşa & 1 & & & $\mathrm{x}$ & \\
\hline 186 & Yazıcı Mehmed Efendi & 3 & & & $\mathrm{x}$ & \\
\hline 187 & Yazıcızâde & 1 & & $\mathrm{x}$ & & \\
\hline 188 & Yildirim & 1 & & & $\mathrm{x}$ & \\
\hline 189 & Yıldırım Bayezid Han & 3 & & & $\mathrm{x}$ & \\
\hline 190 & Yusuf Ağa & 11 & & $\mathrm{x}$ & $\mathrm{x}$ & $\mathrm{x}$ \\
\hline 191 & Zeyni Çelebi & 1 & $\mathrm{x}$ & & & \\
\hline
\end{tabular}

